Article

\title{
A New Dynamic Model to Predict Transient and Steady State PV Temperatures Taking into Account the Environmental Conditions
}

\author{
Socrates Kaplanis ${ }^{1}$ and Eleni Kaplani ${ }^{2, *(1)}$ \\ 1 Renewable Energy Systems Lab, Technological Educational Institute of Western Greece, M. Alexandrou 1, \\ 26334 Patra, Greece; kaplanis@teiwest.gr \\ 2 Engineering, Faculty of Science, University of East Anglia, Norwich NR4 7TJ, UK \\ * Correspondence: e.kaplani@uea.ac.uk; Tel.: +44-1603-591584
}

Received: 30 October 2018; Accepted: 14 December 2018; Published: 20 December 2018

check for updates

\begin{abstract}
Photovoltaic (PV) cell and module temperature profiles, $\mathrm{T}_{\mathrm{c}}$ and $\mathrm{T}_{\mathrm{pv}}$, respectively, developed under solar irradiance were predicted and measured both at transient and steady state conditions. The predicted and measured $\mathrm{T}_{\mathrm{c}}$ or $\mathrm{T}_{\mathrm{pv}}$ covered both a bare c-Si PV cell, by SOLARTEC, at laboratory conditions using a solar light simulator, as well as various c-Si and pc-Si modules (SM55, Bioenergy $195 \mathrm{~W}$, Energy Solutions $125 \mathrm{~W}$ ) operating in field conditions. The time constants, $\tau$, of the $T_{c}$ and $T_{p v}$ profiles were determined by the proposed model and calculated using the experimentally obtained profiles for both the bare PV cell and PV modules. For model validation, the predicted steady state and transient temperature profiles were compared with experimental ones and also with those generated from other models. The effect of the ambient temperature, $T_{a}$, wind speed, $v_{w}$, and the solar irradiance, $\mathrm{I}_{\mathrm{T}}$, on the model performance, as well as of the mounting geometries, was investigated and incorporated in the prediction model. The predicted temperatures had the best matching to the measured ones in comparison to those from six other models. The model developed is applicable to any geographical site and environmental conditions.
\end{abstract}

Keywords: PV cell temperature; transient profiles; time constant; steady state; wind velocity; environmental effects

\section{Introduction}

The photovoltaic (PV) temperature is a significant factor which affects the PV module performance through its effect on the PV cell electric characteristics, analytically presented in PV cell textbooks. Correspondingly, we speak about the PV module temperature, $T_{p v}$, and the PV cell temperature, $T_{c}$, which are equal provided the cells of the module are healthy and experience the same environmental conditions. It is of much interest to develop reliable models to predict $\mathrm{T}_{\mathrm{pv}}$, and the PV performance, through prediction of the power output $\mathrm{P}_{\mathrm{m}}(\mathrm{t})$, when the module operates under any configuration and field conditions. Various mathematical expressions have been proposed and validated on their reliability to predict steady state $\mathrm{T}_{\mathrm{pv}}$ [1-9], as to be discussed in detail later in this paper or transient $\mathrm{T}_{\mathrm{pv}}$ profiles, [10-14] with good accuracy under any field conditions and for Building Integrated Photovoltaic (BIPV) configurations [15-19]. Those $\mathrm{T}_{\mathrm{pv}}$ prediction models are grouped in: explicit models described in [1-7], usually physics based theoretical models which try to incorporate the environmental parameters, mainly, solar irradiance on the PV plane $\mathrm{I}_{\mathrm{T}}$, wind velocity $\mathrm{v}_{\mathrm{w}}$, wind direction, heat transfer from the PV to the environment, and radiation exchanges between PV and environment:

a. Implicit models which use various algorithms and regression analysis to produce formulae to predict $\mathrm{T}_{\mathrm{pv}}$ through quantities which depend on $\mathrm{T}_{\mathrm{pv}}$, as reviewed in $[3,20]$. 
b. Theoretical based semi-empirical models, a mixture of Physics based processes elaborated on implicit functions, which through regression analysis incorporate the environmental conditions and develop expressions to predict $\mathrm{T}_{\mathrm{pv}}$ including geometrical factors like PV module inclination, sun-tracking systems, BIPV [6,8,21].

c. Approaches based on Artificial Neural Networks (ANN) [5,10,22].

An assessment of the $T_{p v}$ prediction models discloses that those which have incorporated the radiation exchanges and the air flow regimes, where heat extraction off the modules is affected specifically, provide values closer to the measured ones [6,7,23-25]. A comparison among the models is necessary as to conclude on the conditions $\mathrm{T}_{\mathrm{pv}}$ is predicted effectively and consistently. It is, therefore, necessary to compare $\mathrm{T}_{\mathrm{pv}}$ models extensively to examine their validity in any PV configuration as the ones studied in [20,26-29].

A time dependent temperature profile is developed in a PV cell when under solar irradiance, $\mathrm{I}_{\mathrm{T}},[8,30]$. The latter is the main factor contributing to the development of the temperature profile in which the ambient temperature $\mathrm{T}_{\mathrm{a}}$ and the wind speed play a role too. This profile has a straight relationship with $\mathrm{I}_{\mathrm{T}}$ at low Concentration Ratio, $\mathrm{C}$, conditions, with $\mathrm{C}<4$, where $\mathrm{C}=\mathrm{I}_{\mathrm{T}} / 10^{3} \mathrm{~W} / \mathrm{m}^{2}$, and a strong dependence on the wind speed, $\mathrm{v}_{\mathrm{w}}$; that is, $\mathrm{T}_{\mathrm{c}}\left(\mathrm{t} ; \mathrm{I}_{\mathrm{T}}, \mathrm{v}_{\mathrm{w}}\right) . \mathrm{T}_{\mathrm{c}}(\mathrm{t})$ depends, also, on the cell structure and the material composition of its layers. Figure 1 shows a section of a PV cell with its characteristic layers which govern the heat conduction causing an effect on the time constant, $\tau$, of the temperature profiles. $T_{c}(t)$ or $T_{p v}(t)$, either the PV module is heated or cooled due to changes in the environmental conditions, is described through an exponential term, $\exp (-t / \tau)$, as discussed in Sections 2 and 3.

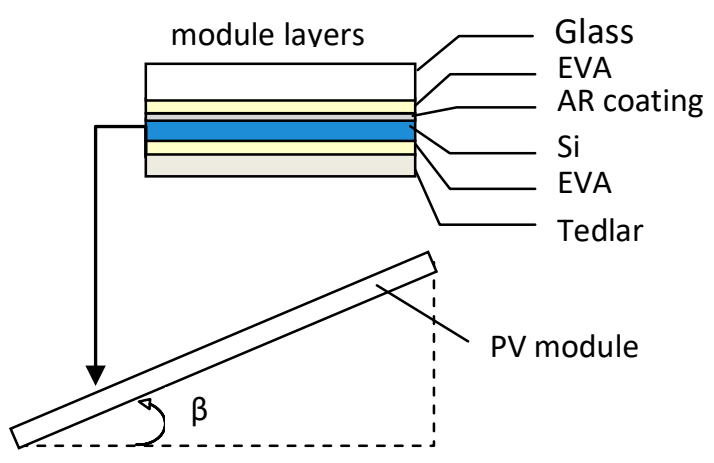

Figure 1. A schematic section of a photovoltaic (PV) module with its characteristic layers. EVA: Ethylene-vinyl Acetate, ARC: Anti-reflective Coating.

The PV cell electric characteristics, short circuit current $\mathrm{I}_{\mathrm{sc}}$, open circuit voltage $\mathrm{V}_{\mathrm{oc}}$ depend on $\mathrm{T}_{\mathrm{c}}(\mathrm{t})$ and on $\mathrm{I}_{\mathrm{T}}$ according to (1) and (2). The prediction of $\mathrm{T}_{\mathrm{c}}(\mathrm{t})$ by the model analytically outlined in this paper and the equations below $[1,11]$, may lead to an excellent $\mathrm{V}_{\mathrm{oc}}(\mathrm{t})$ and $\mathrm{I}_{\mathrm{sc}}(\mathrm{t})$ profile prediction under any operating conditions.

$$
\begin{gathered}
\mathrm{V}_{\mathrm{oc}}\left(\mathrm{I}_{\mathrm{T}}, \mathrm{T}_{\mathrm{c}}\right)=\mathrm{V}_{\mathrm{oc}}\left(\mathrm{I}_{\mathrm{T}, \text { ref }}, \mathrm{T}_{\mathrm{c}, \text { ref }}\right)+\frac{\mathrm{n} \cdot \mathrm{k}}{\mathrm{q}} \cdot \mathrm{T}_{\mathrm{c}} \cdot\left(\ln \mathrm{I}_{\mathrm{T}}-\ln \mathrm{I}_{\mathrm{T}, \mathrm{ref}}\right)+\frac{\mathrm{dV}_{\mathrm{oc}}}{\mathrm{dT} \mathrm{T}_{\mathrm{c}}}\left(\mathrm{T}_{\mathrm{c}}-\mathrm{T}_{\mathrm{c}, \text { ref }}\right) \\
\mathrm{I}_{\mathrm{sc}}\left(\mathrm{I}_{\mathrm{T}}, \mathrm{T}_{\mathrm{c}}\right)=\frac{\mathrm{I}_{\mathrm{T}}}{\mathrm{I}_{\mathrm{T}, \mathrm{ref}}} \mathrm{I}_{\mathrm{ph}}\left(\mathrm{I}_{\mathrm{T}, \text { ref }}, \mathrm{T}_{\mathrm{c}, \text { ref }}\right)-\mathrm{I}_{\mathrm{o}}\left(\exp \left(\frac{\mathrm{I}_{\mathrm{sc}}\left(\mathrm{I}_{\mathrm{T}}, \mathrm{T}_{\mathrm{c}}\right) \cdot \mathrm{R}_{\mathrm{s}}}{\mathrm{n} \cdot \mathrm{k} \cdot \mathrm{T}_{\mathrm{c}} / \mathrm{q}}\right)-1\right)-\frac{\mathrm{I}_{\mathrm{sc}}\left(\mathrm{I}_{\mathrm{T}}, \mathrm{T}_{\mathrm{c}}\right) \cdot \mathrm{R}_{\mathrm{s}}}{\mathrm{R}_{\mathrm{sh}}}
\end{gathered}
$$

Equation (1) has a form outlined in more detail in [1] and explains the $V_{o c}(t) v s$. $T_{c}$ behavior from the very early stage of the transient profile, where it is not a straight line. The fact that $T_{c}(t)$ is affected by $\mathrm{v}_{\mathrm{W}}$, may be used as simple recover agent for both $\mathrm{I}_{\mathrm{sc}}, \mathrm{V}_{\mathrm{oc}}$ and $\mathrm{P}_{\mathrm{m}}$. The degree of the $\mathrm{T}_{\mathrm{c}}$ effect depends indirectly on the PV cell size, especially as $\mathrm{I}_{\mathrm{T}}$ increases, [31]. This is related to the module internal resistance, $R_{s}$ and thus due to Joule effect $P_{m}$ decreases as $I_{T}$ increases, beyond a critical value. 
To reduce the deviations between predicted and measured values of the PV power output $P_{m}(t)$, it is necessary that the model provides accurate $T_{c}(t)$ results. This is the objective of this research project whose final outcome is a formula built on theoretical background and regression analysis and predicts $\mathrm{T}_{\mathrm{pv}}$ under any environmental conditions. The predicted $\mathrm{T}_{\mathrm{pv}}$ values provide the correction required for an accurate estimation of the PV power output which is necessary for online monitoring, control and diagnostic purposes in PV installations.

\section{2. $T_{p v}$ Prediction Models for Steady State and Transient Conditions}

$\mathrm{T}_{\mathrm{c}}(\mathrm{t})$ or $\mathrm{T}_{\mathrm{pv}}(\mathrm{t})$ may be obtained theoretically by building the Energy Balance Equation (EBE) for any PV cell or module with conversion efficiency $\eta_{c}$ and incident solar radiation $I_{T}$. A fraction $\eta_{c} I_{T} d t$ of the intensity of the global solar radiation on the cell is converted into electricity, while the rest $\left(1-\eta_{\mathrm{c}}\right) \mathrm{I}_{\mathrm{T}} \mathrm{dt}$ is converted into heat, assuming a negligible reflection. The heat propagates to both sides front and back, whereof it is transferred to the environment by convection, with coefficients $h_{c, f}$ and $h_{c, b}$ for the front and back side, respectively, and by infrared (IR) radiated heat with coefficients $h_{r, f}$ and $h_{r, b}$ for the front and back side respectively. The coefficients $h_{c, f}, h_{c, b}, h_{r, f}$, and $h_{r, b}$ depend on the surface conditions, geometry and the thermal and environmental conditions that the PV cell operates. Therefore, all possible factors related to the mode of heat transfer from the cell surface to the environment must be considered, either it is natural flow, forced flow, or mixed; the type of the air flow, laminar or turbulent; also, the wind velocity and its angle of incidence relative to the PV cell plane. The formulae to estimate the coefficients $h_{r, f}, h_{r, b}, h_{c, f}$ and $h_{c, b}$ for any of the above conditions are elaborated and discussed critically in [23,32-34]. Typical values of the physico-thermal properties of the cell components with their usual dimensions are provided in Table 1 which was developed based on data from $[17,35,36]$. These data are required to estimate the resistance due to conduction within the cell, the mass heat capacity $(\mathrm{mc})$, and the $\mathrm{T}_{\mathrm{c}}(\mathrm{t})$ or $\mathrm{T}_{\mathrm{pv}}(\mathrm{t})$ time constant, $\tau$.

Table 1. Characteristic, average values of the thickness $\delta x$, conductivity $k$, density $\rho$, specific heat capacity $c_{p}$, mass heat capacity $m c$ and thermal resistance $R_{k}$ normalised to surface area, for the PV cell components.

\begin{tabular}{ccccccc}
\hline Material & $\boldsymbol{\delta} \mathbf{x}(\mathbf{m})$ & $\mathbf{K}(\mathbf{W} / \mathbf{m K})$ & $\boldsymbol{\rho} \mathbf{( \mathbf { k g } / \mathbf { m } ^ { 3 } )}$ & $\mathbf{c}_{\mathbf{p}}(\mathbf{J} / \mathbf{k g K})$ & $\begin{array}{c}\left(\mathbf{m c}=\boldsymbol{\rho c}_{\mathbf{p}} \mathbf{A}_{\mathbf{c}} \delta \mathbf{x}\right) / \mathbf{A}_{\mathbf{c}} \\
\left(\mathbf{J} / \mathbf{K m} \mathbf{K m}^{\mathbf{2}}\right)\end{array}$ & $\begin{array}{c}\mathbf{R}_{\mathbf{k}}=\delta \mathbf{x} / \mathbf{k} \mathbf{A}_{\mathbf{c}} \\
\mathbf{( K / \mathbf { W } )}\end{array}$ \\
\hline Glass * & $0.003-0.004$ & $1.0-1.4$ & $2500-3000$ & 500 & 4500 & $3 \times 10^{-3}$ \\
ARC & $100 \times 10^{-9}$ & 32 & 2400 & 691 & 0.165 & $3.13 \times 10^{-9}$ \\
EVA & $250 \times 10^{-6}$ & 0.35 & 960 & 2090 & 502 & $714 \times 10^{-6}$ \\
Cell & $225 \times 10^{-6}$ & 148 & 2330 & 677 & 355 & $1.52 \times 10^{-6}$ \\
EVA & $250 \times 10^{-6}$ & 0.35 & 960 & 2090 & 502 & $714 \times 10^{-6}$ \\
Tedlar ${ }^{* *}$ & 0.0001 & 0.2 & 1200 & $1000-1760$ & 150 & $5 \times 10^{-4}$ \\
\hline
\end{tabular}

${ }^{*}$ Glass $\mathrm{c}_{\mathrm{p}}$ ranges from $600-750 \mathrm{~J} / \mathrm{kgK}$ based on its composition; ${ }^{* *}$ Tedlar/PET/Tedlar (TPT) or Tedlar/PET/Ethylen primer (TPE), surface density $380-480 \mathrm{~g} / \mathrm{m}^{2}$, thickness $=0.3-0.4 \mathrm{~mm}$, Tedlar $\mathrm{c}_{\mathrm{p}}=1760 \mathrm{~J} / \mathrm{kgK}$ for UV screening glass. The $c_{p}$ of TPT or TPE is almost the same as of the Tedlar.

Figure 2 shows the coefficient $f=\mathrm{f}\left(\mathrm{t} ; \mathrm{I}_{\mathrm{T}}, \mathrm{v}_{\mathrm{W}}\right)$ given by Equations (3) and (4) vs. the hour in a mid-day of March with $\mathrm{v}_{\mathrm{W}}$ and $\mathrm{I}_{\mathrm{T}}$ as parameters, determined both for the fixed inclination (FIX) and double-axis sun tracking (ST) PV systems. Coefficient $f$ and $\mathrm{T}_{\mathrm{pv}}$ are given by the expressions, $[12,21,37]$.

$$
\begin{gathered}
\mathrm{T}_{\mathrm{pv}}=\mathrm{T}_{\mathrm{a}}+f \mathrm{I}_{\mathrm{T}} \\
F=\left[(\tau \alpha)-\eta_{\mathrm{c}}\right] /\left[\mathrm{U}_{\mathrm{f}}+\mathrm{U}_{\mathrm{b}}\right]
\end{gathered}
$$

The strong effect of $\mathrm{v}_{\mathrm{w}}$ on $f$ is shown in Figure 2 where for an increase in $\mathrm{v}_{\mathrm{w}}$ from 1 to $3.3 \mathrm{~m} / \mathrm{s}, f$ decreases by $28.5 \%$ in the ST to $46.6 \%$ in the FIX. In absolute values, $f$ changed by 0.01 for the ST and $0.02 \mathrm{~m}^{2} \mathrm{~K} / \mathrm{W}$ for FIX. Based on these results and Equation (3), the $\mathrm{T}_{\mathrm{pv}}$ generally follows the $f$ profile. The heat losses coefficients from the front and back PV sides, $U_{f}$ and $U_{b}$ respectively are represented by $\mathrm{U}_{\mathrm{g}-\mathrm{a}}$ and $\mathrm{U}_{\mathrm{b}-\mathrm{a}}$ respectively according to: 


$$
\begin{aligned}
& \mathrm{U}_{\mathrm{g}-\mathrm{a}}=\mathrm{h}_{\mathrm{c}, \mathrm{f}}+\mathrm{h}_{\mathrm{r}, \mathrm{f}} \\
& \mathrm{U}_{\mathrm{b}-\mathrm{a}}=\mathrm{h}_{\mathrm{c}, \mathrm{b}}+\mathrm{h}_{\mathrm{r}, \mathrm{b}}
\end{aligned}
$$

The PV module temperature in the front side, $\mathrm{T}_{\mathrm{g}}$, is generally higher than $\mathrm{T}_{\mathrm{b}}$ at the back at steady state conditions by $2-3{ }^{\circ} \mathrm{C}$ [16]. However, this figure may not be taken for granted and might be even reversed as it depends on the PV cell structural details, the specific heat capacity of each one of the cell components, their thickness, conductivity, and emissivity coefficients $\varepsilon_{\mathrm{g}}$ and $\varepsilon_{\mathrm{b}}$ of the PV glass cover and backsheet respectively, as well as the $\mathrm{v}_{\mathrm{w}}$ along with its angle of incidence on the module, either windward or leeward [23].

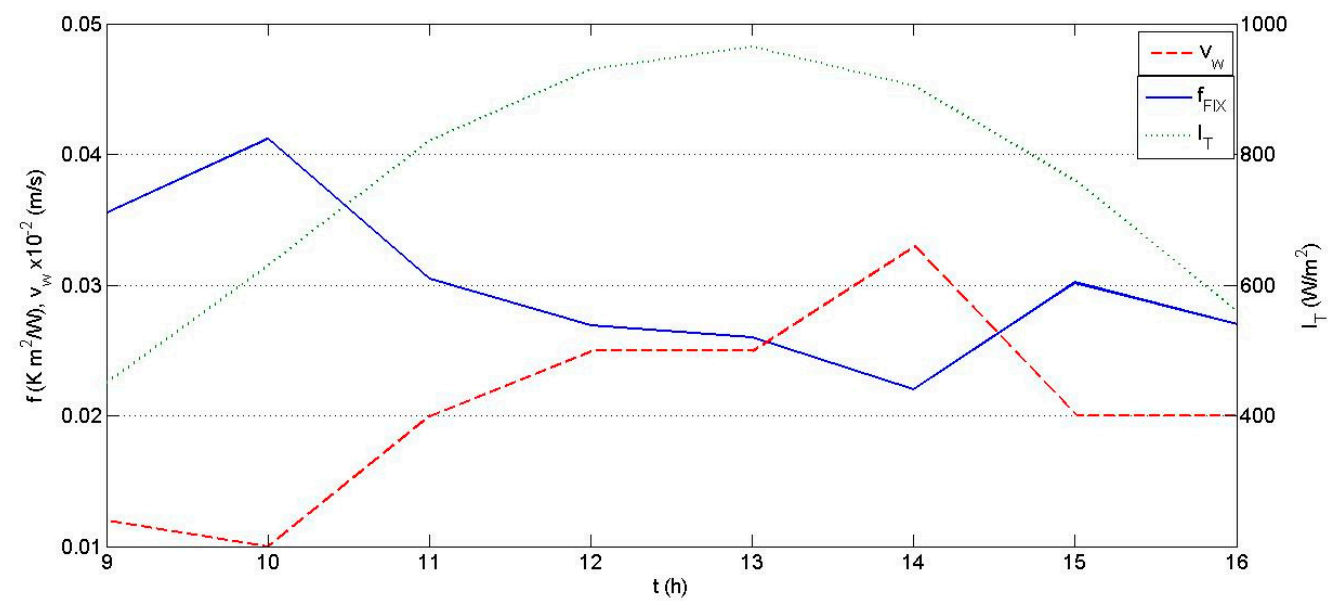

(a)

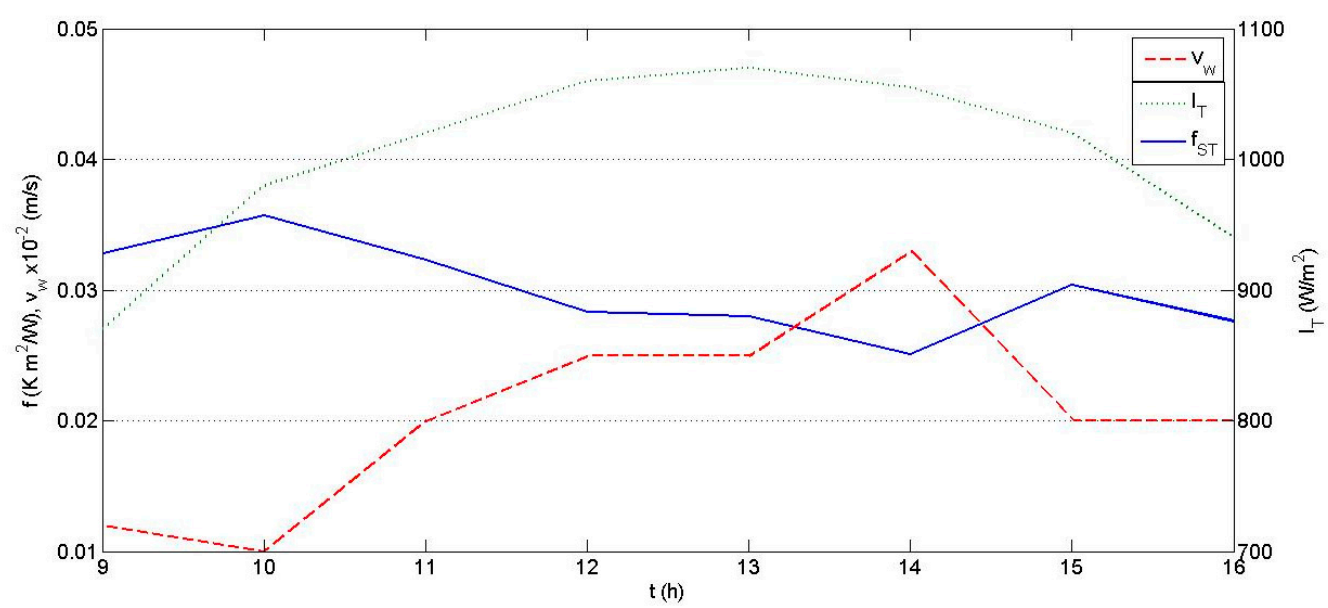

(b)

Figure 2. $f$ versus $\mathrm{t}$ as determined for the mid-day of March with parameters $\mathrm{v}_{\mathrm{W}}$ and $\mathrm{I}_{\mathrm{T}}$. The strong impact of $\mathrm{v}_{\mathrm{W}}$ on $f$ is obvious. (a) Corresponds to the FIX PV system and (b) to the sun tracking (ST) one.

\subsection{Steady State $T_{p v}$ Prediction Models}

The steady state $\mathrm{T}_{\mathrm{pv}}$ or $\mathrm{T}_{\mathrm{c}}$ may be estimated by using formulas derived in this work and others proposed in [1-7]. Usually, there is no discrimination between $T_{c}$ with the $T_{f}$ or $T_{g}$ and the $T_{b}$, which stand for the cell, glass, and back cover PV temperatures, respectively. Those temperatures will be analytically determined by the model proposed in Section 2.2. They differ to each other depending on the PV cell structure, PV cell type, the thermo-physical properties and the mounting e.g., for Building Adapted Photovoltaics (BAPV), PV thermal (PV/T) [37-41]. 
Various Formulae for the $\mathrm{T}_{\mathrm{pv}}$ Prediction at Steady State Conditions:

$$
\mathrm{T}_{\mathrm{pv}}=\mathrm{T}_{\mathrm{a}}+\mathrm{f}\left(\mathrm{v}_{\mathrm{w}} ; \eta_{\mathrm{pv}}\right) \mathrm{I}_{\mathrm{T}}
$$

$f$ may be expressed as a function of $\mathrm{v}_{\mathrm{W}}$, and $\delta \eta_{\mathrm{pv}}$ according to the model proposed, Equations (8)-(10),

$$
f=\mathrm{f}\left(\mathrm{v}_{\mathrm{w}} ; \eta_{\mathrm{pv}}\right)=\mathrm{f}\left(\mathrm{v}_{\mathrm{w}}\right)\left(1-\delta \eta_{\mathrm{pv}} /\left(1-\eta_{\mathrm{pv}, \mathrm{m}}\right)\right)
$$

$\delta \eta_{\mathrm{pv}}=\eta_{\mathrm{pv}}-\eta_{\mathrm{pv}, \mathrm{m}}$ where, $\eta_{\mathrm{pv}, \mathrm{m}}$ is the PV efficiency at the average conditions, $\left(\mathrm{T}_{\mathrm{a}}=20^{\circ} \mathrm{C}, \mathrm{I}_{\mathrm{T}}=\right.$ $\left.800 \mathrm{~W} / \mathrm{m}^{2}\right)$, during the experiments carried out and which are used as reference. The regression analysis of one year's monitored data $\left(\mathrm{I}_{\mathrm{T}}, \mathrm{T}_{\mathrm{a}}, \mathrm{T}_{\mathrm{pv}}, \mathrm{v}_{\mathrm{w}}\right.$ ) from a pc-Si PV (Energy Solutions $125 \mathrm{~W}_{\mathrm{p}}$ module) generator gave for $\mathrm{f}\left(\mathrm{v}_{\mathrm{w}} ; \eta_{\mathrm{pv}}\right)$ a quadratic $\mathrm{v}_{\mathrm{w}}$ function multiplied with a correction function standing for the change in $\eta_{p v}$ due to deviations of the environmental conditions from the average values mentioned above.

$$
\left.\mathrm{f}\left(\mathrm{v}_{\mathrm{w}} ; \eta_{\mathrm{pv}}\right)=\left(\mathrm{a}+\mathrm{bv}_{\mathrm{w}}+\mathrm{cv}_{\mathrm{w}}{ }^{2}\right)\left(1-\delta \eta_{\mathrm{pv}} /\left(1-\eta_{\mathrm{pv}, \mathrm{m}}\right)\right) \quad \text { (the proposed model }\right)
$$

$a, b$, and c values when the PV module is at open rack conditions are given in (10)

$$
\begin{gathered}
\mathrm{f}\left(\mathrm{v}_{\mathrm{w}} ; \eta_{\mathrm{pv}}\right)=\left(0.0381-0.00428 \mathrm{v}_{\mathrm{w}}+0.000196 \mathrm{v}_{\mathrm{w}}{ }^{2}\right)\left(1-\delta \eta_{\mathrm{pv}} /\left(1-\eta_{\mathrm{pv}, \mathrm{m}}\right)\right) \\
\mathrm{T}_{\mathrm{pv}}=\mathrm{T}_{\mathrm{a}}+\mathrm{I}_{\mathrm{T}} /\left(\mathrm{U}_{\mathrm{o}}+\mathrm{U}_{1} \mathrm{v}_{\mathrm{w}}\right) \quad \text { model [2] }
\end{gathered}
$$

$\mathrm{U}_{\mathrm{o}}$ takes values from 23.5 to $26.5 \mathrm{~W} / \mathrm{m}^{2} \mathrm{~K}$, with an average $25.5 \mathrm{~W} / \mathrm{m}^{2} \mathrm{~K} ; \mathrm{U}_{1}$ takes values from 6.25 to $7.68 \mathrm{~W} / \mathrm{m}^{2} \mathrm{~K}$, with an average $6.84 \mathrm{~W} / \mathrm{m}^{2} \mathrm{~K}$.

$$
\mathrm{T}_{\mathrm{c}}=\mathrm{T}_{\mathrm{a}}+\mathrm{I}_{\mathrm{T}} \exp \left(\mathrm{a}+\mathrm{bv}_{\mathrm{w}}\right) \quad \text { model [1] }
$$

$\mathrm{a}$ and $\mathrm{b}$ are provided in Table 2, below.

Table 2. Values of the parameters a and b. Data from [1].

\begin{tabular}{cccc}
\hline Type of Module & Mount & $\mathbf{a}^{*}$ & $\mathbf{b}^{*}$ \\
\hline Glass-cell-polymer sheet & Open rack & -3.56 & -0.0750 \\
Glass-cell-polymer sheet & Insulated back & -2.81 & -0.0455 \\
\hline \multicolumn{2}{c}{ * for values of a and b for different type of modules and configurations, see [1]. }
\end{tabular}

The $\left(\mathrm{T}_{\mathrm{pv}}-\mathrm{T}_{\mathrm{a}}\right) / \mathrm{I}_{\mathrm{T}}$ equal to $f$, Equation (7), was fitted onto a quadratic function given by (13),

$$
f \times 10^{3}=0.0712 \mathrm{v}_{\mathrm{w}}{ }^{2}-2.411 \mathrm{v}_{\mathrm{w}}+32.96 \text { for } \mathrm{v}_{\mathrm{w}}<18 \mathrm{~m} / \mathrm{s} \text { with } \mathrm{v}_{\mathrm{w}} \text { at } 10 \mathrm{~m} \quad \text { model [7] }
$$

$\mathrm{T}_{\mathrm{pv}}$ is then estimated from $\mathrm{T}_{\mathrm{pv}}=\mathrm{T}_{\mathrm{a}}+f \mathrm{I}_{\mathrm{T}}$

$$
\begin{gathered}
\mathrm{T}_{\mathrm{pv}}=0.943 \mathrm{~T}_{\mathrm{a}}+0.028 \mathrm{I}_{\mathrm{T}}-1.528 \mathrm{v}_{\mathrm{W}}+4.3 \quad \operatorname{model}[5] \\
\mathrm{T}_{\mathrm{c}}=\mathrm{T}_{\mathrm{a}}+\omega\left(0.32 /\left(8.91+2 \mathrm{v}_{\mathrm{F}}\right)\right) \mathrm{I}_{\mathrm{T}} \quad \mathrm{v}_{\mathrm{F}}=\mathrm{v}_{\mathrm{W}} / 0.67 \quad \text { model [3] }
\end{gathered}
$$

where $\omega=1$, according to [3], as this paper addresses free standing PV. The $v_{F}=v_{W, p}$ which is the parallel component of $\mathrm{v}_{\mathrm{W}}$ on the PV plane

$$
T_{c}=\left[U_{p v} \cdot T_{a}+I_{T}\left[\left((\tau \alpha)-\eta_{r}\right)-\mu T_{r}\right] /\left(U_{p v}-\mu I_{T}\right) \quad \text { model }[4]\right.
$$

where, $\mu=0.05 \% /{ }^{\circ} \mathrm{C}, \mathrm{T}_{\mathrm{r}}=25^{\circ} \mathrm{C}$ and $\eta_{\mathrm{r}}$ is the reference efficiency of the PV cell or module. 
2.2. The Proposed Prediction Model for the Transient Profile $T_{c}(t)$ or Generally, $T_{p v}(t)$

To obtain theoretically the $T_{c}(t)$ profile the following set of energy balance equations is developed for the characteristic PV module components, that is, glass, cell and back sheet,

$$
\begin{gathered}
(\mathrm{mc})_{c} \mathrm{dT}_{\mathrm{c}} / \mathrm{dt}=\mathrm{A}_{\mathrm{c}}\left[\left((\tau \alpha)-\eta_{\mathrm{c}}\right) \mathrm{I}_{\mathrm{T}}-\mathrm{U}_{\mathrm{c}-\mathrm{g}}\left(\mathrm{T}_{\mathrm{c}}-\mathrm{T}_{\mathrm{g}}\right)-\mathrm{U}_{\mathrm{c}-\mathrm{b}}\left(\mathrm{T}_{\mathrm{c}}-\mathrm{T}_{\mathrm{b}}\right)\right] \\
(\mathrm{mc})_{g} \mathrm{dT}_{\mathrm{g}} / \mathrm{dt}=\mathrm{A}_{\mathrm{c}}\left[\mathrm{U}_{\mathrm{c}-\mathrm{g}}\left(\mathrm{T}_{\mathrm{c}}-\mathrm{T}_{\mathrm{g}}\right)-\mathrm{U}_{\mathrm{g}-\mathrm{a}}\left(\mathrm{T}_{\mathrm{g}}-\mathrm{T}_{\mathrm{a}}\right)\right] \\
\left(\mathrm{mc}_{\mathrm{b}} \mathrm{dT}_{\mathrm{b}} / \mathrm{dt}=\mathrm{A}_{\mathrm{c}}\left[\mathrm{U}_{\mathrm{c}-\mathrm{b}}\left(\mathrm{T}_{\mathrm{c}}-\mathrm{T}_{\mathrm{b}}\right)-\mathrm{U}_{\mathrm{b}-\mathrm{a}}\left(\mathrm{T}_{\mathrm{b}}-\mathrm{T}_{\mathrm{a}}\right)\right]\right.
\end{gathered}
$$

where:

$$
\begin{gathered}
\mathrm{U}_{\mathrm{c}-\mathrm{g}}=1 / \mathrm{R}_{\mathrm{c}-\mathrm{g}}=1 /\left(\delta \mathrm{x}_{\text {Cell }} / 2 \mathrm{k}_{\text {Cell }}+\delta \mathrm{x}_{\mathrm{ARC}} / \mathrm{k}_{\mathrm{ARC}}+\delta \mathrm{x}_{\mathrm{EVA}} / \mathrm{k}_{\mathrm{EVA}}+\delta \mathrm{x}_{\mathrm{Glass}} / \mathrm{k}_{\mathrm{Glass}}\right) \\
\mathrm{U}_{\mathrm{c}-\mathrm{b}}=1 / \mathrm{R}_{\mathrm{c}-\mathrm{b}}=1 /\left(\delta \mathrm{x}_{\text {Cell }} / 2 \mathrm{k}_{\text {Cell }}+\delta \mathrm{x}_{\mathrm{EVA}} / \mathrm{k}_{\mathrm{EVA}}+\delta \mathrm{x}_{\text {Tedlar }} / \mathrm{k}_{\text {Tedlar }}\right)
\end{gathered}
$$

The corresponding values of the above properties are shown in Table 1.

For the case of a bare PV cell the optical factor $(\tau \alpha)$ in (17) is nearly equal to 1 , and the $\mathrm{U}_{\mathrm{g}-\mathrm{a}}$ and $\mathrm{U}_{\mathrm{b}-\mathrm{a}}$ for the front and back side were assumed to be equal. This is acceptable in case the PV cell is positioned at vertical and there is no wind on the cell. Hence, $T_{g}$ and $T_{b}$ in this case are equal to a very good approximation. Based on the continuity of the heat flow from the cell to the environment the following formula holds, too,

$$
\mathrm{U}_{\mathrm{c}-\mathrm{a}}\left(\mathrm{T}_{\mathrm{c}}-\mathrm{T}_{\mathrm{a}}\right)=\mathrm{U}_{\mathrm{g}-\mathrm{a}}\left(\mathrm{T}_{\mathrm{g}}-\mathrm{T}_{\mathrm{a}}\right)+\mathrm{U}_{\mathrm{b}-\mathrm{a}}\left(\mathrm{T}_{\mathrm{b}}-\mathrm{T}_{\mathrm{a}}\right)
$$

Equation (21) gives the heat flow from the cell to the glass cover which equals the one from the front, i.e., glass cover to the environment and Equation (22) from the cell to the back cover and the back cover to the environment.

$$
\begin{aligned}
& U_{c-g}\left(T_{c}-T_{g}\right)=U_{g-a}\left(T_{g}-T_{a}\right) \\
& U_{c-b}\left(T_{c}-T_{b}\right)=U_{b-a}\left(T_{b}-T_{a}\right)
\end{aligned}
$$

The derivatives $\mathrm{dT}_{\mathrm{g}} / \mathrm{dt}$ and $\mathrm{dT}_{\mathrm{c}} / \mathrm{dt}$ with respect to $\mathrm{dT}_{\mathrm{b}} / \mathrm{dt}$ are derived from (20)-(22),

$$
\begin{gathered}
\mathrm{dT}_{\mathrm{c}} / \mathrm{dt}=\left[\left(\mathrm{U}_{\mathrm{c}-\mathrm{b}}+\mathrm{U}_{\mathrm{b}-\mathrm{a}}\right) / \mathrm{U}_{\mathrm{c}-\mathrm{b}}\right] \mathrm{dT}_{\mathrm{b}} / \mathrm{dt} \\
\mathrm{dT}_{\mathrm{g}} / \mathrm{dt}=\left[\mathrm{U}_{\mathrm{c}-\mathrm{g}} /\left(\mathrm{U}_{\mathrm{c}-\mathrm{g}}+\mathrm{U}_{\mathrm{g}-\mathrm{a}}\right)\right] \mathrm{dT}_{\mathrm{c}} / \mathrm{dt}=\left[\mathrm{U}_{\mathrm{c}-\mathrm{g}} /\left(\mathrm{U}_{\mathrm{c}-\mathrm{g}}+\mathrm{U}_{\mathrm{g}-\mathrm{a}}\right)\right]\left[\left(\mathrm{U}_{\mathrm{c}-\mathrm{b}}+\mathrm{U}_{\mathrm{b}-\mathrm{a}}\right) / \mathrm{U}_{\mathrm{c}-\mathrm{b}}\right] \mathrm{dT} \mathrm{T}_{\mathrm{b}} / \mathrm{dt}
\end{gathered}
$$

Adding (17)-(19), using (20)-(24), rearranging the terms and making the proper substitutions, the following 2 groups of relationships are obtained as in Sections 2.2.1 and 2.2.2 and lead to the estimation of $\mathrm{T}_{\mathrm{c}}(\mathrm{t})$ and $\mathrm{T}_{\mathrm{b}}(\mathrm{t})$.

2.2.1. The Relationships to Determine $\mathrm{T}_{\mathrm{c}}(\mathrm{t})$

$$
\begin{gathered}
\mathrm{dT}_{\mathrm{c}} / \mathrm{dt}=\mathrm{A}_{\mathrm{c}}\left[\left((\tau \alpha)-\eta_{\mathrm{c}}\right) \mathrm{I}_{\mathrm{T}}-\mathrm{U}_{\mathrm{c}-\mathrm{a}}\left(\mathrm{T}_{\mathrm{c}}-\mathrm{T}_{\mathrm{a}}\right)\right] /(\mathrm{mc})_{\mathrm{ef}}=\mathrm{F}_{1}-\mathrm{F}_{2}(\mathrm{U})\left(\mathrm{T}_{\mathrm{c}}-\mathrm{T}_{\mathrm{a}}\right) \\
(\mathrm{mc})_{\mathrm{ef}}=(\mathrm{mc})_{\mathrm{c}}+\left((\mathrm{mc})_{\mathrm{EVA}}+(\mathrm{mc})_{\mathrm{g}}\right)\left[\mathrm{U}_{\mathrm{c}-\mathrm{g}} /\left(\mathrm{U}_{\mathrm{c}-\mathrm{g}}+\mathrm{U}_{\mathrm{g}-\mathrm{a}}\right)\right]+\left((\mathrm{mc})_{\mathrm{EVA}}+(\mathrm{mc})_{\mathrm{b}}\right)\left[\mathrm{U}_{\mathrm{c}-\mathrm{b}} /\left(\mathrm{U}_{\mathrm{c}-\mathrm{b}}+\mathrm{U}_{\mathrm{b}-\mathrm{a}}\right)\right] \\
\mathrm{F}_{2}(\mathrm{U})=\mathrm{A}_{\mathrm{c}} \mathrm{U}_{\mathrm{c}-\mathrm{a}} /(\mathrm{mc})_{\mathrm{ef}} \\
\mathrm{F}_{1}=\mathrm{A}_{\mathrm{c}}\left((\tau \alpha)-\eta_{\mathrm{c}}\right) \mathrm{I}_{\mathrm{T}} /(\mathrm{mc})_{\mathrm{ef}}
\end{gathered}
$$

2.2.2. The Relationships to Determine $T_{b}(t)$

$$
\mathrm{dT}_{\mathrm{b}} / \mathrm{dt}=\mathrm{F}_{1}-\mathrm{F}_{2}(\mathrm{U})\left(\mathrm{T}_{\mathrm{b}}-\mathrm{T}_{\mathrm{a}}\right)
$$




$$
\begin{gathered}
(\mathrm{mc})_{\mathrm{ef}}=\left((\mathrm{mc})_{\mathrm{b}}+(\mathrm{mc})_{\mathrm{EVA}}\right)+(\mathrm{mc})_{\mathrm{c}}\left[\left(\mathrm{U}_{\mathrm{c}-\mathrm{b}}+\mathrm{U}_{\mathrm{b}-\mathrm{a}}\right) / \mathrm{U}_{\mathrm{c}-\mathrm{b}}\right]+\left((\mathrm{mc})_{\mathrm{EVA}}+(\mathrm{mc})_{\mathrm{g}}\right)\left[\left(\mathrm{U}_{\mathrm{c}-\mathrm{g}} /\left(\mathrm{U}_{\mathrm{c}-\mathrm{g}}+\mathrm{U}_{\mathrm{g}-\mathrm{a}}\right)\right]\right. \\
{\left[\left(\mathrm{U}_{\mathrm{c}-\mathrm{b}}+\mathrm{U}_{\mathrm{b}-\mathrm{a}}\right) / \mathrm{U}_{\mathrm{c}-\mathrm{b}}\right]}
\end{gathered}
$$

In this subsection, $\mathrm{F}_{1}$ and $\mathrm{F}_{2}(\mathrm{U})$ are given by:

$$
\begin{gathered}
\mathrm{F}_{1}=\mathrm{A}_{\mathrm{c}}\left((\tau \alpha)-\eta_{\mathrm{c}}\right) \mathrm{I}_{\mathrm{T}} /(\mathrm{mc})_{\mathrm{ef}} \\
\mathrm{F}_{2}(\mathrm{U})=\mathrm{A}_{\mathrm{c}}\left[\mathrm{U}_{\mathrm{b}-\mathrm{a}}+\mathrm{U}_{\mathrm{g}-\mathrm{a}}\left[\left(1+\left(\mathrm{U}_{\mathrm{b}-\mathrm{a}} / \mathrm{U}_{\mathrm{c}-\mathrm{b}}\right)\right) /\left(1+\left(\mathrm{U}_{\mathrm{g}-\mathrm{a}} / \mathrm{U}_{\mathrm{c}-\mathrm{g}}\right)\right)\right]\right] /(\mathrm{mc})_{\mathrm{ef}}
\end{gathered}
$$

Based on (29), $T_{b}(t)$ is provided by the algorithmic expression below, which is part of the model proposed:

$$
\left[F_{1}-F_{2}(U)\left(T_{b}(t+\delta t)-T_{a}\right)\right] /\left[F_{1}-F_{2}(U)\left(T_{b}(t)-T_{a}\right)\right]=\exp (-\delta t / \tau)
$$

$\mathrm{T}_{\mathrm{b}}(\mathrm{t}+\delta \mathrm{t})$ is the PV backside temperature at time interval $\mathrm{t}+\delta \mathrm{t}$, and $\mathrm{T}_{\mathrm{b}}(\mathrm{t})$ at time $t$. Time intervals $\delta t$ may be equal to a practical time unit. Equation (33) allows for introducing $I_{T}(t+\delta t)$ and $I_{T}(t)$ to Equation (31) and for using $\mathrm{v}_{\mathrm{w}}(\mathrm{t})$ to estimate $\mathrm{U}_{\mathrm{g}-\mathrm{a}}$ and $\mathrm{U}_{\mathrm{b}-\mathrm{a}}$ from equations in [23] taking into account the environmental conditions in that time interval $[t, t+\delta t]$ and introducing the values to (32). For the $T_{c}(t)$ the same expression is used where instead of $T_{b}$ is $T_{c}$ and the factors $F_{2}(U)$ and $(m c)_{e f}$ are given in Section 2.2.1. In all cases, the time constant of the PV module temperature profile $(\tau)$ is given by:

$$
\tau=1 / F_{2}(U)
$$

For the estimation of the time constants, $\tau_{\mathrm{b}}, \tau_{\mathrm{g}}, \tau \mathrm{c}$ appropriate $(\mathrm{mc})_{\mathrm{ef}}$ and $\mathrm{F}_{2}(\mathrm{U})$ are used in (34). $\mathrm{F}_{2}(\mathrm{U})$ for the $\mathrm{T}_{\mathrm{b}}(\mathrm{t})$ prediction tends to:

$$
\mathrm{F}_{2}(\mathrm{U})=\mathrm{A}_{\mathrm{c}}\left(\mathrm{U}_{\mathrm{b}-\mathrm{a}}+\mathrm{U}_{\mathrm{g}-\mathrm{a}}\right) /(\mathrm{mc})_{\mathrm{ef}}
$$

provided that $\mathrm{U}_{\mathrm{c}-\mathrm{g}}$ and $\mathrm{U}_{\mathrm{c}-\mathrm{b}}$ have high values compared to $\mathrm{U}_{\mathrm{b}-\mathrm{a}}$ and $\mathrm{U}_{\mathrm{g}-\mathrm{a}}$ and for $\mathrm{U}_{\mathrm{b}-\mathrm{a}}=\mathrm{U}_{\mathrm{g}-\mathrm{a}}$

$$
\mathrm{F}_{2}(\mathrm{U})=2 \mathrm{~A}_{\mathrm{c}} \mathrm{U}_{\mathrm{b}-\mathrm{a}} /(\mathrm{mc})_{\mathrm{ef}}=\mathrm{U}_{\mathrm{b}-\mathrm{a}} /\left((\rho \mathrm{c})_{\mathrm{ef}} \mathrm{L}_{\mathrm{c}}\right)
$$

Hence, in simplified cases the time constant, $\tau$, of the $T_{\mathcal{c}}(t)$ profile is given by:

$$
\tau=(\rho c)_{\mathrm{ef}} \mathrm{L}_{\mathrm{c}} / \mathrm{U}_{\mathrm{b}-\mathrm{a}}
$$

The $(\rho c)_{\text {ef }}$ for the c-Si cell is taken from Table 1 data and is estimated by the sum of the products of the density and the specific heat capacity of every component of the PV cell. $\mathrm{L}_{\mathrm{c}}$ is the characteristic length of the cell for the heat propagation process from inside the cell to outside, which is equal to the ratio of the PV cell volume $(\mathrm{V})$ over its total surface. In this case, $\mathrm{L}_{\mathrm{c}}$ due to the very small cell thickness is equal to the half of the PV cell thickness. In such simplified cases, recurrence formulae like in [11] are used, while Equations (23)-(32) are opted to get accurate $T_{c}(t), T_{b}(t)$ and $T_{f}(t)$ prediction under any environmental conditions. From Equations (34)-(37) becomes clear that $\tau$ increases with (mc) ef that is, with the glass and back sheet thickness, which mostly contribute to $(\mathrm{mc})_{\mathrm{ef}}$ and inversely decreases with $v_{W}$ (see Figure 2) or with the friction of air flow on the PV back side due to $U_{f}$ and $U_{b}$ increase.

\section{Results}

\subsection{The Experimental Set Up}

The experimental set up includes a Data Acquisition System, a solar simulator model Solar Light 16S-300-002 Class A Air Mass 1.5 emission spectrum, as well as the simulation model to predict $T_{p v}(t)$, $\mathrm{V}_{\mathrm{oc}}(\mathrm{t})$ and $\mathrm{I}_{\mathrm{sc}}(\mathrm{t})$. Also, thin diameter $\mathrm{Cu}$-Const thermocouples attached at the PV cell or module back side to monitor $\mathrm{T}_{\mathrm{b}}(\mathrm{t})$, a Pt 100 for the ambient temperature and a series of c-Si bare cells and several 
c-Si and pc-Si modules mounted on FIX and ST frames installed at free environment. According to the data acquisition system used in the experiments data were collected and recorded every $1 \mathrm{~s}$.

\subsection{Predicted and Measured Transient $T_{b}(t)$ Profiles for Bare $c$-Si Cells}

Figure 3 shows the measured and predicted profile of a SOLARTEC $2.5 \times 2.5 \mathrm{~cm}^{2} \mathrm{c}$-Si part of a cell under $\mathrm{I}_{\mathrm{T}}=10^{3} \mathrm{~W} / \mathrm{m}^{2}$ at controlled environmental conditions in the laboratory, by using Equations (33)-(36). The deviation between the measured $T_{b \text {,meas }}(t)$ and predicted $T_{b}$,pred $(t)$ values is less than $3 \%$ throughout the transient period. Thus, the theoretical and experimental $\tau$ values for the bare cell are practically the same as discussed below. The time constant, $\tau$, was predicted from the expression $(\mathrm{mc})_{\mathrm{ef}} /\left(\mathrm{U}_{\mathrm{f}}+\mathrm{U}_{\mathrm{b}}\right)$, given in Equations (34) and (35). The (mc) $)_{\mathrm{ef}}$ normalized to the bare cell surface is equal to $857 \mathrm{~J} / \mathrm{m}^{2} \mathrm{~K}$ based on Table 1 data. The appropriate equations from [23] gave $U_{f}=U_{b}=11.5-12 \mathrm{~W} / \mathrm{m}^{2} \mathrm{~K}$ at air free flow for $T_{b}$ in the range $20-50{ }^{\circ} \mathrm{C}$ and $16-20{ }^{\circ} \mathrm{C}$ indoor temperature and therefore, $\tau$ was determined in the range of 35.7-37.3 s compared to the experimental $37.1 \mathrm{~s}$, which was estimated by fitting the function $T_{b}(t)=a-b \cdot \exp (-t / \tau)$ on the $T_{b}(t)$ measured values. The deviation of the theoretical $\tau$ from the experimental one was less than $3.8 \%$. The predicted $\mathrm{T}_{\mathrm{b} \text {,pred }}(\mathrm{t})$ were introduced into (1) to obtain $\mathrm{V}_{\mathrm{oc}}(\mathrm{t})$, as in Figure 4 , where predicted and experimentally determined $V_{o c}(t)$ are shown. A maximum difference of $6 \mathrm{mV}$ is observed at the saturation time period of $5 \tau$ to $6 \tau$. This corresponds to $1.1 \%$ deviation between measured and predicted values. It is noted that the $V_{o c}(t)$ time constant, was determined experimentally, as done with the $T_{b}(t)$, by fitting an exponential function on the data.

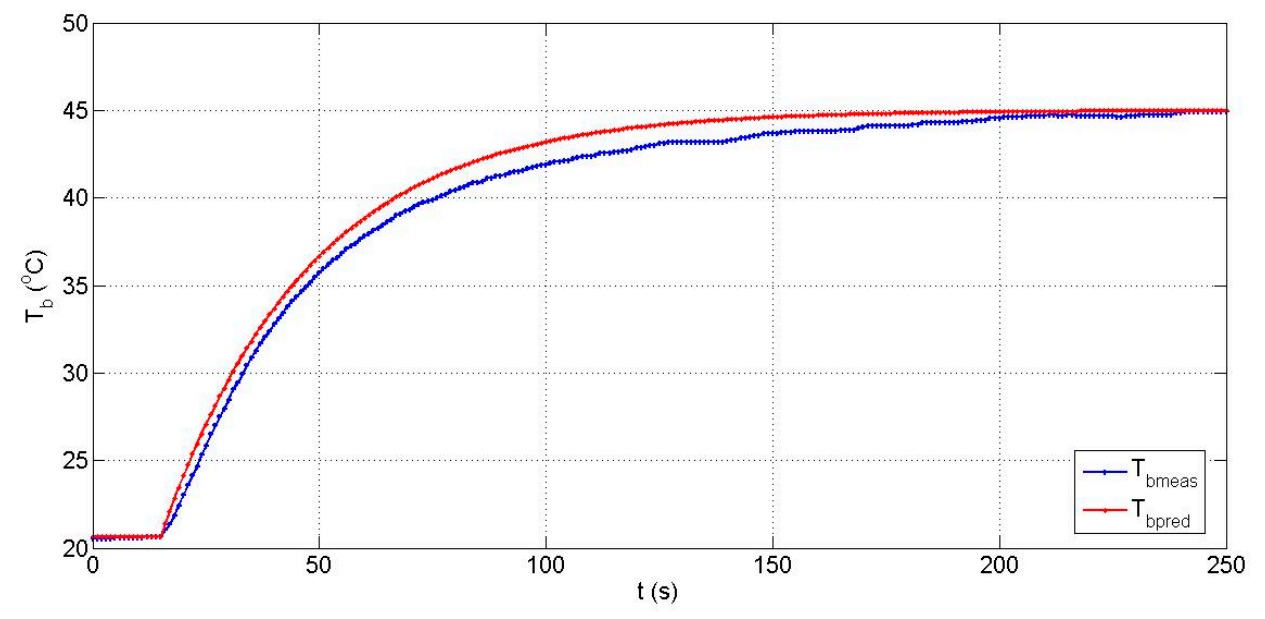

Figure 3. Predicted $\mathrm{T}_{\mathrm{b} \text {,pred }}(\mathrm{t})$ and measured $\mathrm{T}_{\mathrm{b} \text {,meas }}(\mathrm{t})$ profiles of a c-Si bare cell in controlled laboratory conditions.

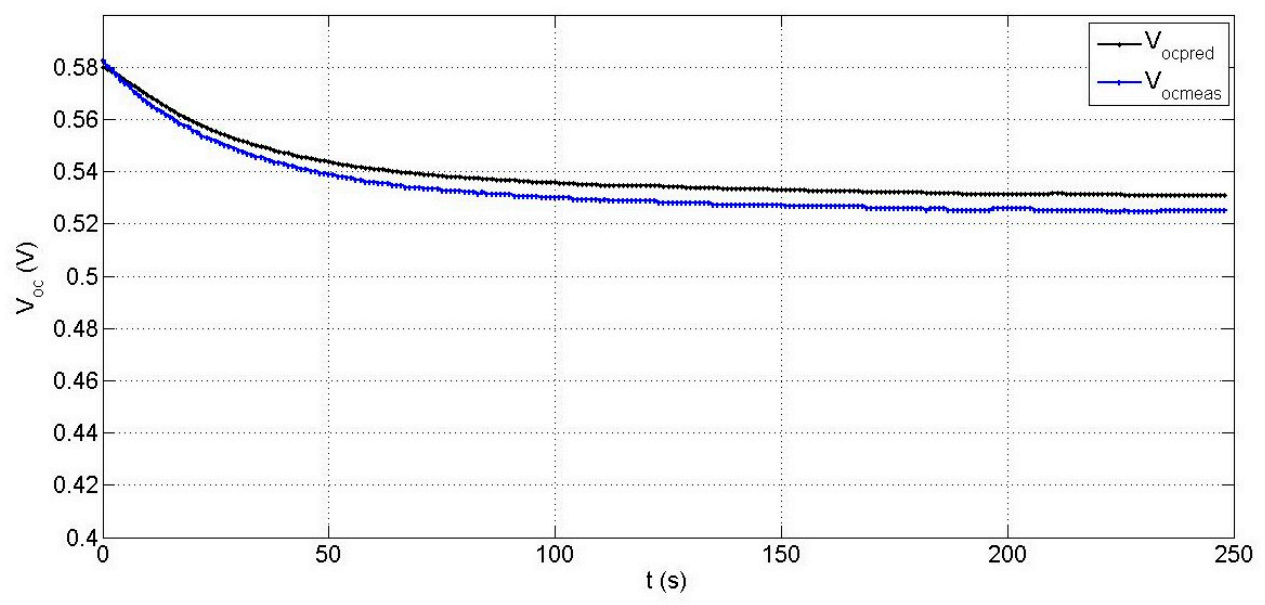

Figure 4. Predicted $V_{\text {oc,pred }}(t)$ and measured $V_{o c, m e a s}(t)$ profiles for a bare c-Si cell in controlled laboratory conditions. 
According to (1) the $\tau$ of $\mathrm{V}_{\mathrm{oc}}(\mathrm{t})$ is the same with the $\mathrm{T}_{\mathrm{b}}(\mathrm{t})$ time constant determined from the curve analysis of Figure 3, equal to $37.1 \mathrm{~s}$. Fitting the function $a+b \cdot \exp (-t / \tau)$ on the measured $V_{o c}(t)$ the result was $\tau=37.2 \mathrm{~s}$. Similarly, a good practical estimation of $\tau$ is obtained from the $V_{o c}(t)$ curve, Figure 4 , using the value of $6 \tau$ at saturation which is in the range of $215-225 \mathrm{~s} / 6=35.8-37.5 \mathrm{~s}$. From (1) the sign of the derivative of $T_{p v}(t)$ is opposite to the corresponding of $V_{o c}(t)$.

\subsection{Predicted and Measured Transient $T_{b}(t)$ Profiles and Time Constants, $\tau$, for PV Modules}

The improved set of the abovementioned iterative relationships which provide transient profiles, end up to the steady state value,

$$
\mathrm{T}_{\mathrm{b}}=\mathrm{T}_{\mathrm{a}}+\left((\tau \alpha)-\eta_{\mathrm{pv}}\right) \mathrm{I}_{\mathrm{T}} /\left(\mathrm{U}_{\mathrm{f}}+\mathrm{U}_{\mathrm{b}}\right)
$$

$\mathrm{T}_{\mathrm{b}}$ obtained from (38) lies very close to $\mathrm{T}_{\mathrm{pv}}$ at saturation predicted in the previous section, provided that proper values for $\eta_{p v}$ and $\left(U_{f}+U_{b}\right)$ are substituted in the above expression. For $(\tau \alpha)$ $=0.91$ (bare cell) $\eta_{\mathrm{pv}}=0.15$ (manufacturer value), $\left(\mathrm{U}_{\mathrm{f}}+\mathrm{U}_{\mathrm{b}}\right)=24 \mathrm{~W} / \mathrm{m}^{2} \mathrm{~K}$, as above, and $\mathrm{T}_{\mathrm{a}}=16^{\circ} \mathrm{C}$, Equation (38) gives $\mathrm{T}_{\mathrm{b}}=47.6^{\circ} \mathrm{C}$ compared to the $44.8{ }^{\circ} \mathrm{C}$ predicted, i.e., a $5.8 \%$ deviation.

Figure 5 gives measured $\mathrm{T}_{b}(\mathrm{t})$ of a PV module Bioenergy 195W. $\tau$ was experimentally determined by the curve fitting analysis and found equal to $\tau=316.7 \mathrm{~s}$. For the theoretical prediction of $\tau$, the total heat losses coefficient at field conditions with low $\mathrm{v}_{\mathrm{w}}$ was given above equal to $24 \mathrm{~W} / \mathrm{m}^{2} \mathrm{~K}$. According to the values from Table 1, the (mc) ef normalized to surface $A_{c}$ for this module, with $3.2 \mathrm{~mm}$ glass and PET back sheet of $0.4 \mathrm{~mm}$, is estimated in the range of $6760-7720$ depending on the $c_{p}$ of the glass cover. Hence, $\tau=[6760-7720]: 24=281.7-321.6 \mathrm{~s}$. In fact, the experimental $\tau$ lies inside the domain of the theoretically predicted $\tau$ values.

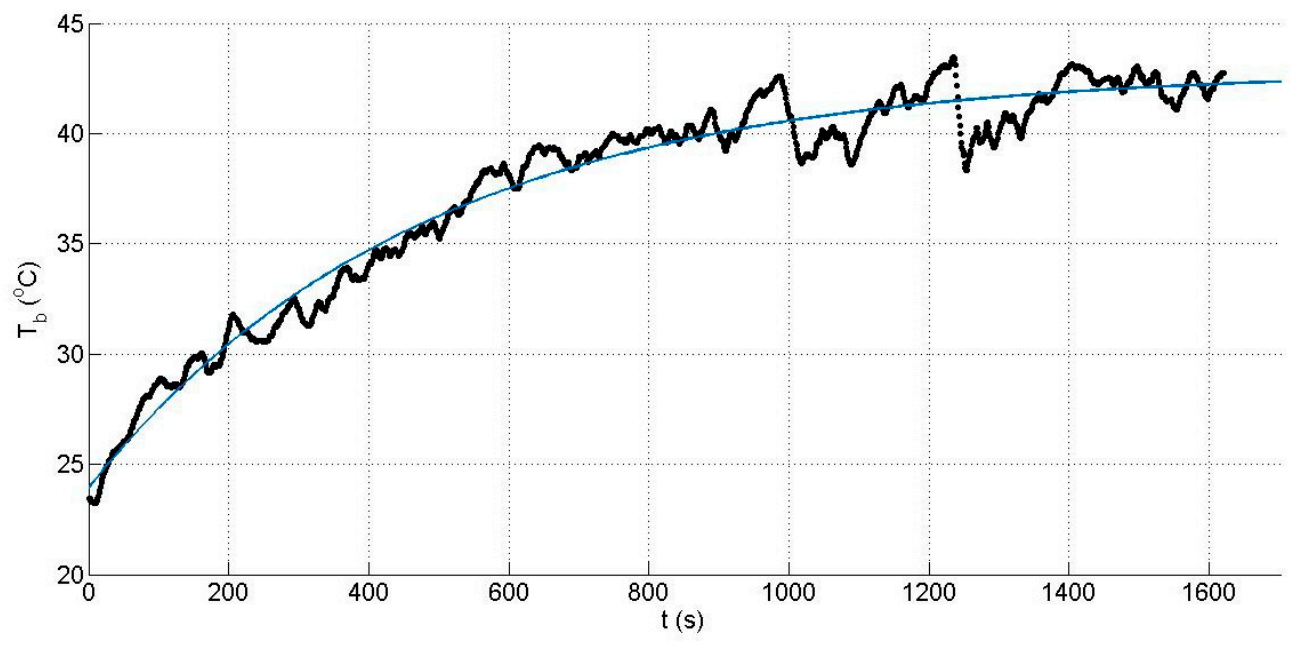

Figure 5. $\mathrm{T}_{b}(\mathrm{t})$ profile for a c-Si Bioenergy 195W PV module in field conditions.

Figure 6 shows the $\mathrm{T}_{\mathrm{b}}(\mathrm{t})$ profile of an SM55 module inclined over a window as shadow hanger and power generator, too. The expression $\mathrm{F}(\mathrm{x})=\mathrm{A}(1-\exp (-\mathrm{Bx}))+\mathrm{C}$ was fitted on the data, (upper curve) with $R^{2}=0.959$, and gave $\tau=306.2 \mathrm{~s}$ while the predicted value was determined by setting $(\mathrm{mc})_{\mathrm{ef}}$ $6760 \mathrm{~J} / \mathrm{m}^{2} \mathrm{~K}$ (considered for the lower size SM55) and $23-24 \mathrm{~W} / \mathrm{m}^{2} \mathrm{~K}$ for the heat losses coefficient. Thus, $\tau$ lies in the range $281.7-293.9 \mathrm{~s}$ with a deviation of its average from the experimental $<6 \%$. However, the wind speed increases at around $1100 \mathrm{~s}$ and steady state temperature reached earlier, see lower curve in Figure 6, where the final time constant due to the wind increase shortened $\tau$ to $235.7 \mathrm{~s}$, according to the curve analysis. Using (39) [4], a theoretical estimate of $\tau$, is obtained.

$$
\mathrm{U}=\mathrm{h}_{\mathrm{c}, \mathrm{f}}+\mathrm{h}_{\mathrm{c}, \mathrm{b}}=11.34+7.73 \mathrm{v}
$$


which for average wind speed during the experiments $\mathrm{v}=1 \mathrm{~m} / \mathrm{s}$, as the PV module, operating as a shadow hanger, was in wind protected zone, $\mathrm{U}=19.07 \mathrm{~W} / \mathrm{m}^{2} \mathrm{~K}$. Adding $10 \mathrm{~W} / \mathrm{m}^{2} \mathrm{~K}$ for $\mathrm{h}_{\mathrm{r}, \mathrm{f}}+\mathrm{h}_{\mathrm{r}, \mathrm{b}}$ then, $\mathrm{U}_{\mathrm{pv}}=29.07 \mathrm{~W} / \mathrm{m}^{2} \mathrm{~K}$ and hence, $\tau=6760 / 29.07=232.5 \mathrm{~s}$ which is a very good prediction. That shows the strong effect of $\mathrm{v}_{\mathrm{W}}$ on PV performance.

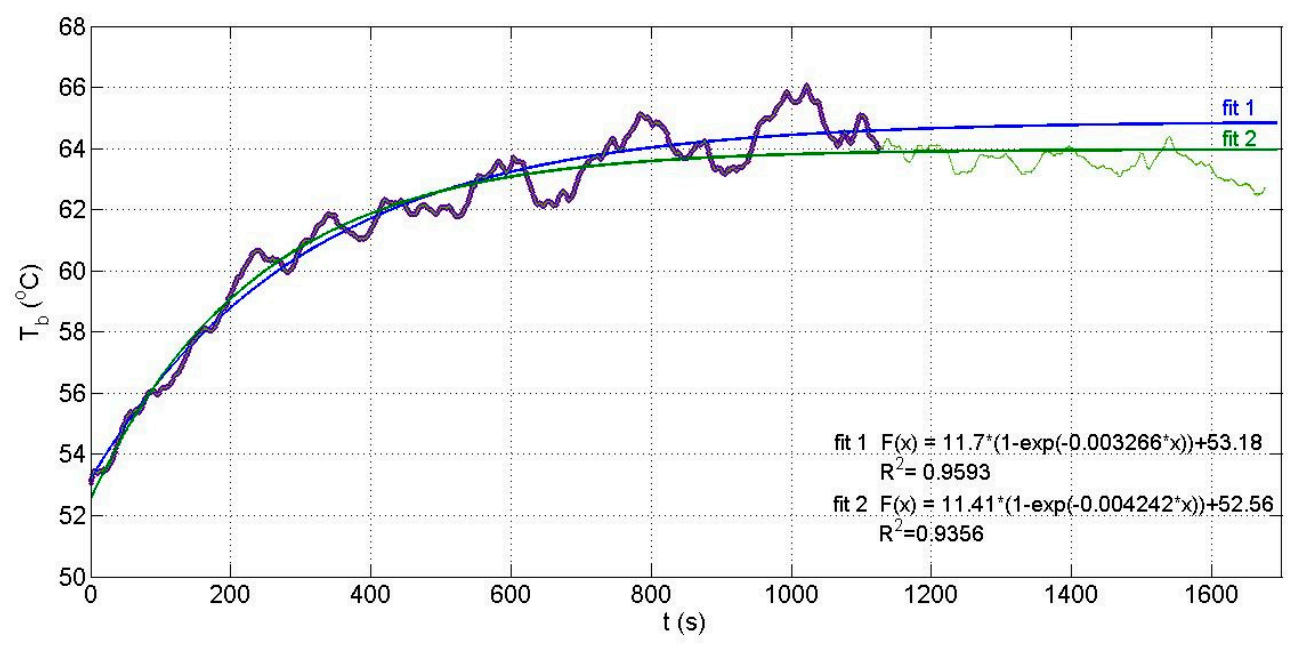

Figure 6. $\mathrm{T}_{\mathrm{b}}(\mathrm{t})$ profile SM55 module placed inclined over a window in a Building Adapted Photovoltaics (BAPV) configuration.

3.4. Predicted Steady State $T_{b}(t)$ Values and Comparison with Measured Data and Results from other Models: Validation of the Proposed Model

The steady state $\mathrm{T}_{\mathrm{b}}$ and the $f$ values of pc-Si PV modules operating in field conditions in FIX and ST mounting were experimentally determined and theoretically predicted. The experiments for both FIX and ST PV systems were carried out in months of different environmental conditions, January and July. $\mathrm{T}_{\mathrm{b}}$ and $f$ were predicted by:

a. the simulation model elaborated and proposed in this article, Equation (10), and

b. formulae provided from the other models $[1-5,7]$.

Those $f$ and $\mathrm{T}_{\mathrm{pv}}$ values were compared with the experimentally determined ones, shown in Table 3.

Table 3. Comparison of predicted by this model $\left(\mathrm{T}_{\mathrm{c}}-\mathrm{T}_{\mathrm{a}}\right)$ for morning-noon-afternoon hours in a mid-day of July with the measured values from the FIX and ST and those calculated using models [1-5].

\begin{tabular}{ccccccccccccccc}
\hline Hour & \multicolumn{3}{c}{ Model [1] } & \multicolumn{2}{c}{ Model [2] } & \multicolumn{2}{c}{ Model [4] } & \multicolumn{2}{c}{ Model [3] } & \multicolumn{2}{c}{ This Model } & \multicolumn{2}{c}{ Model [5] } & \multicolumn{2}{c}{ Measured * } \\
\hline & F & ST & F & ST & F & ST & F & ST & F & ST & F & ST & F & ST \\
\hline $\mathbf{1 0}$ & 12.9 & 24 & 11.4 & 21.3 & 10.15 & 18.8 & 11.25 & 21.0 & 13.6 & 25.3 & 12.5 & 24.1 & 14.0 & 23.0 \\
$\mathbf{1 2}$ & 20.5 & 27.3 & 19.9 & 26.5 & 16.25 & 26.9 & 20.0 & 26.6 & 23.3 & 27.1 & 20.4 & 27.2 & 23.5 & 27.3 \\
$\mathbf{1 4}$ & 23.2 & 28.2 & 22.2 & 27.1 & 19 & 22.2 & 22.3 & 27.2 & 24.1 & 28.5 & 22.9 & 28.0 & 24.0 & 29.0 \\
$\mathbf{1 6}$ & 16.7 & 24 & 13 & 18.7 & 12.75 & 18.55 & 12.52 & 18.05 & 16.5 & 24 & 15.4 & 23.8 & 17 & 23 \\
\hline \multicolumn{1}{c}{ * The fixed inclination (FIX) and ST systems were installed at free environment. }
\end{tabular}

In addition, Table 4 gives the $f$ values predicted by this model, (10), and also by the known models [1-5,7] during the hours in a mid-day of July and January. In the application presented $T_{a}, v_{w}$ and $\mathrm{I}_{\mathrm{T}}$ change during the day and the two PV generators sun-tracker and fixed inclination system having identical modules were used. Hence, the tests included two different PV mountings and varying environmental conditions. 
Table 4. The predicted by this model $f$ values compared with those calculated using models [1-5,7] and the experimentally determined ones, for various hours of a mid-day of January and July under various environmental conditions, $\mathrm{I}_{\mathrm{T}}$ and $\mathrm{v}_{\mathrm{W}}$. Both cases of FIX and ST PV systems were considered.

\begin{tabular}{|c|c|c|c|c|c|c|c|c|c|c|c|}
\hline Hour/Type & $\mathbf{I}_{\mathbf{T}}$ & $\mathrm{T}_{\mathrm{c}}-\mathrm{T}_{\mathrm{a}}$ & $\overline{\mathbf{v}_{\mathbf{w}}}$ & $f_{\exp }{ }^{*}$ & $f_{\text {model }}$ & Model [2] & Model [7] & Model [1] & Model [5] & Model [4] & Model [3] \\
\hline $14 \mathrm{~h} / 7 /$ FIX & 840 & 24.5 & 2.0 & 0.0291 & 0.0303 & 0.0255 & 0.0305 & 0.0245 & 0.0285 & 0.0276 & 0.0278 \\
\hline $11 \mathrm{~h} / 7 /$ FIX & 623 & 17 & 3.8 & 0.0272 & 0.0267 & 0.0195 & 0.0248 & 0.0215 & 0.0227 & 0.0203 & 0.0202 \\
\hline $16 \mathrm{~h} / 7 / \mathrm{ST}$ & 970 & 23 & 4.2 & 0.0237 & 0.0235 & 0.0184 & 0.0240 & 0.0208 & 0.0237 & 0.0196 & 0.0185 \\
\hline $16 \mathrm{~h} / 7 /$ FIX & 680 & 16 & 4.2 & 0.0235 & 0.0236 & 0.0184 & 0.0240 & 0.0208 & 0.0227 & 0.0220 & 0.0185 \\
\hline $12 \mathrm{~h} / 1 / \mathrm{ST}$ & 1050 & 35 & 1.0 & 0.0335 & 0.0340 & 0.0309 & 0.0307 & 0.0264 & 0.0305 & 0.0366 & 0.0300 \\
\hline $14 \mathrm{~h} / 1 / \mathrm{ST}$ & 1020 & 30.5 & 2.5 & 0.0299 & 0.0286 & 0.0235 & 0.0273 & 0.0236 & 0.0284 & 0.0266 & 0.0264 \\
\hline $14 \mathrm{~h} / 1 /$ FIX & 800 & 26.5 & 2.5 & 0.0330 & 0.0340 & 0.0235 & 0.0273 & 0.0236 & 0.0286 & 0.0250 & 0.0264 \\
\hline $13 \mathrm{~h} / 1 / \mathrm{ST}$ & 1080 & 34.5 & 1.5 & 0.0318 & 0.0337 & 0.0280 & 0.0295 & 0.0254 & 0.0290 & 0.0332 & 0.0322 \\
\hline $13 \mathrm{~h} / 1 / \mathrm{FIX}$ & 860 & 30.5 & 1.5 & 0.0355 & 0.0330 & 0.0280 & 0.0295 & 0.0254 & 0.0316 & 0.0330 & 0.0322 \\
\hline $8 \mathrm{~h} / 7 / \mathrm{ST}$ & 625 & 19 & 1.2 & 0.0304 & 0.0318 & 0.0297 & 0.0302 & 0.0260 & 0.0295 & 0.0360 & 0.0343 \\
\hline
\end{tabular}


It is clear from Table 3 that the proposed model has an overall higher prediction performance over the other models. For this, a statistical analysis on both Tables data provides the consistency and the prediction quality of the models, as shown in Figure 7.

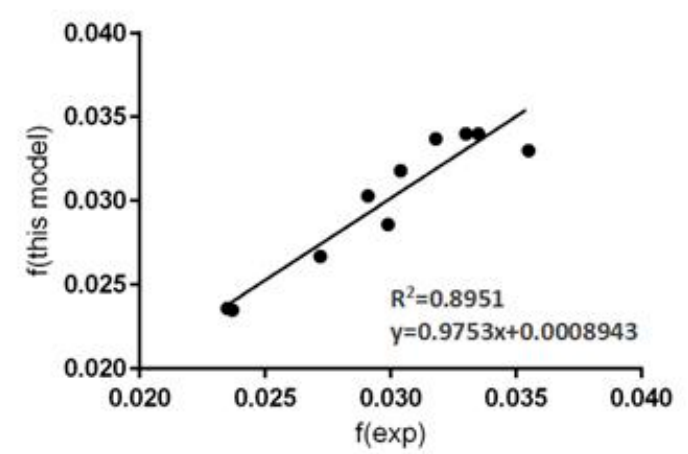

(a)

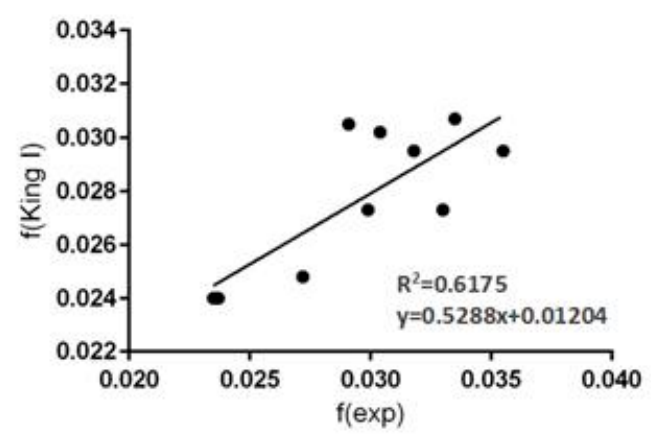

(c)

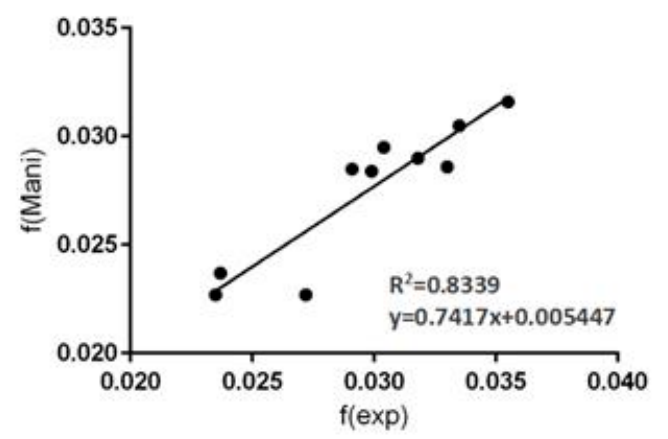

(e)

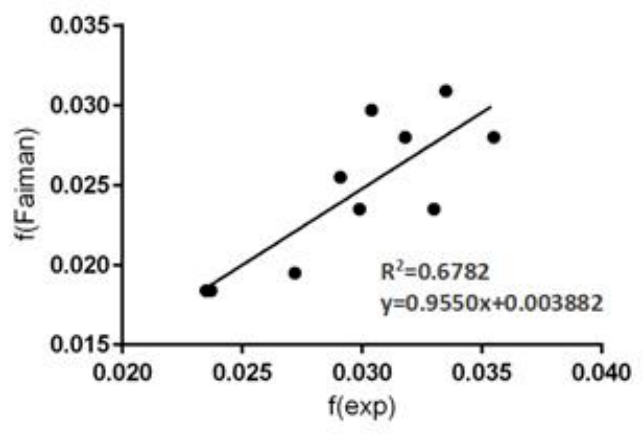

(b)

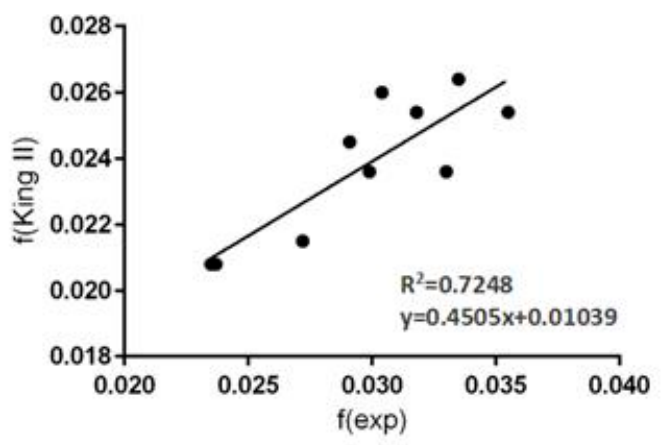

(d)

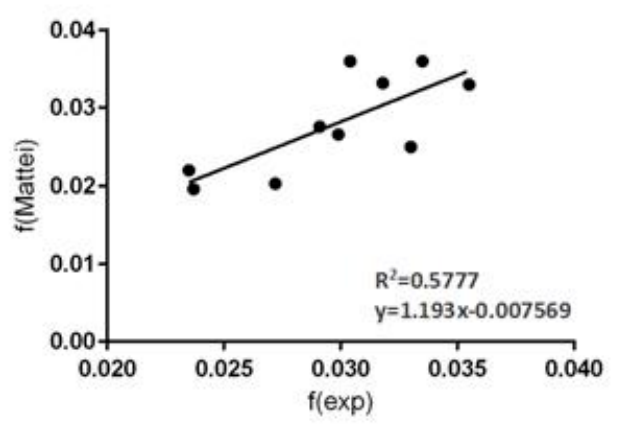

(f)

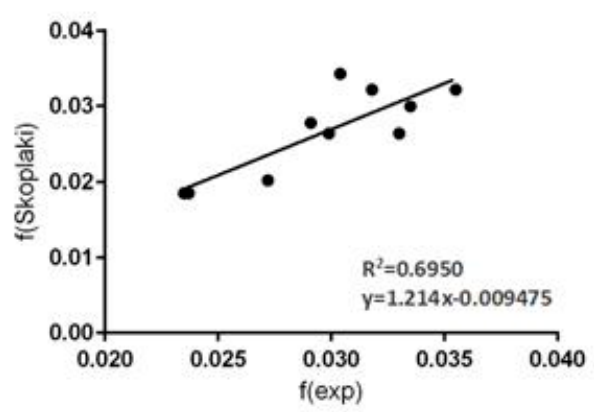

$(\mathrm{g})$

Figure 7. Results from a regression analysis of predicted $f$ values versus the experimentally determined $f$ values where $f$ is predicted by (a) the proposed model, (b) model [2], (c) model [1], (d) model [7], (e) model [5], (f) model [4], and (g) model [3]. 
From the results deployed in Tables 3 and 4 it is clear that the proposed model predicts $f$ and $\mathrm{T}_{\mathrm{pv}}$ for FIX and ST configurations systematically very close to the experimentally determined values with deviation less than $4 \%$. The predicted values from models $[1-5,7]$ experience a larger dispersion disclosed by the determination coefficient, $R^{2}$, while their deviations may in general reach up to $15 \%$. In general, the models which do not provide correction due to the effect of $\mathrm{I}_{\mathrm{T}}, \mathrm{T}_{\mathrm{a}}$ on $\eta_{\mathrm{pv}}$ exhibit higher deviation compared to this model. Figure $7 \mathrm{a}-\mathrm{g}$ show the predicted by this model and the models $[1-5,7] f$ values versus the experimental ones. The model proposed exhibits the least dispersion of data and is nearer to the best theoretical line.

\section{Discussion}

The measured $\mathrm{T}_{\mathrm{b}}(\mathrm{t})$ values either for the bare PV cell or the PV modules were best fitted on the function a $\left(1-\exp \left(\mathrm{t} / \tau_{\mathrm{Tc}}\right)\right)$, with a coefficient of determination always $>0.998$, which provided for the $\tau_{T c}$. $T_{b}(t)$ and $\tau$ were also predicted theoretically from Equations (29)-(34) accounting for the environmental conditions. The predicted $\mathrm{T}_{\mathrm{b}}$ values for a cell deviated by $<3 \%$ from the measured ones. Both depend on $\mathrm{I}_{\mathrm{T}}, \mathrm{V}_{\mathrm{W}}$ and the PV geometrical and physico-chemical characteristics, as in Table 1. The dependence on $\mathrm{I}_{\mathrm{T}}$ creeps in through the heat transfer coefficients as $\mathrm{U}_{\mathrm{g}-\mathrm{a}}$ and $\mathrm{U}_{\mathrm{b}-\mathrm{a}}$ increase with the $\mathrm{T}_{\mathrm{b}}$, which in turn increases with $\mathrm{I}_{\mathrm{T}}$. A formula proposed to predict $\tau_{\mathrm{Tc}}$ directly based on Equations (37) and (39) gave very good results, which deviated by $<5 \%$ from the experimental value. Using more accurate expressions for the $U_{f}$ and $U_{b}$ as proposed by the authors in [23], would result in much smaller deviations between the predicted and experimental values but would raise the algorithmic complexity of the model which requires the use of many theoretical expressions to accurately simulate $\mathrm{T}_{\mathrm{pv}}$ as analyzed in $[23,24]$, rather than the mixed type compact model proposed here which was the aim of the current work. For the bare c-Si $\tau_{\mathrm{Tc}}$ was found equal to $35.8 \mathrm{~s}-37.1 \mathrm{~s}$ for $\mathrm{I}_{\mathrm{T}}=10^{3} \mathrm{~W} / \mathrm{m}^{2}$, while for c-Si and pc-Si PV modules the $\tau_{\mathrm{Tc}}$ value was around 4.5-5.5 min. For $\mathrm{v}_{\mathrm{w}}$ higher than $1-2 \mathrm{~m} / \mathrm{s}, \tau$ decreased to $2-2.5 \mathrm{~min}$. This is explained through Equations (32) and (34) where the effect of environmental conditions is expressed through the total effect of $U_{b-a}$ and $U_{g-a}$ which inversely affects $\tau$. Note that $U_{c-b}$ and $U_{c-g}$ are much larger than $U_{b-a}$ and $U_{g-a}$ respectively and therefore the ratio $\left(1+\left(\mathrm{U}_{\mathrm{b}-\mathrm{a}} / \mathrm{U}_{\mathrm{c}-\mathrm{b}}\right)\right) /\left(1+\left(\mathrm{U}_{\mathrm{g}-\mathrm{a}} / \mathrm{U}_{\mathrm{c}-\mathrm{g}}\right)\right)$ tends to 1 . Therefore, the effect of the characteristics of the layers of the module on the time constant is expressed mainly through $(\mathrm{mc})_{\mathrm{ef}}$ in Equations (32) and (34), which proportionally affects $\tau$. For example, the effect of the EVA encapsulant alone is significant as may be estimated using Equation (30) for the modules used in the study the EVA has $15 \%$ contribution in the module $(\mathrm{mc})_{\mathrm{ef}}$ value, leading to a larger time constant (by $15 \%$ ) and more pronounced transient phenomena.

The predicted $T_{c}(t)$ was used to predict $V_{o c}(t)$. The result was in excellent agreement with the experimental values for $\mathrm{I}_{\mathrm{T}}=10^{3} \mathrm{~W} / \mathrm{m}^{2}$. The time constants, $\tau_{\mathrm{Voc}}$, of the theoretically developed $\mathrm{V}_{\mathrm{oc}}(\mathrm{t})$ profiles by using (1) lie very close to the experimentally determined ones. The transient prediction model is easily handled even for $\mathrm{I}_{\mathrm{T}}$ and $\mathrm{v}_{\mathrm{W}}$ changing during monitoring. The introduction of the $I_{T}(t)$ and $v_{W}(t)$ values into the algorithm, Equations (31)-(33), is done using their average values in each time unit. The recorded steady state $T_{b}$ values during the hours of the mid-day of 2 climatically opposite months, July and January, were compared with the predicted values. An excellent agreement was confirmed and the diagram of the predicted by this model $f$ values versus experimental ones was of higher quality compared to the other models. It is important to underline that the constants $a, b$, $c$ in Equations (9) and (10) were derived by regression analysis of data taken from the operation of 7 years old pc-Si modules. Therefore, an ageing correction, of +7 years $\times 0.85 \% /$ year $=+6 \%$ must be added in the predicted $f$ values obtained from the other models [1-3,7], provided that those models were developed using brand new PV modules. Thus, a good improvement will be achieved in their prediction performance. Finally, it is emphasized that the experimentally determined $f$ and $\mathrm{T}_{\mathrm{b}}$ values used in the validation test were excluded from the data used in the regression analysis to build the $f\left(\mathrm{v}_{\mathrm{w}}\right)$ quadratic formula. 
The model developed applies to free standing PV modules or cells in any environmental conditions. It is based on c-Si PV modules but could be easily adapted to flat plate PV modules of other types as long as the properties of Table 1 are enriched for the layers and composition of these types. The model would need to be adapted for PV modules inclined before windows and BIPV as it concerns the view factor and the convection coefficients. The steady state model takes into account wind velocity but not wind direction, while module inclination is not considered. These can be integrated into the model through $\mathrm{U}_{\mathrm{f}}$ and $\mathrm{U}_{\mathrm{b}}$ as in [23] and will be presented in future work.

\section{Conclusions}

A new model to predict the steady state PV cell or module temperature, $\mathrm{T}_{\mathrm{pv}}$ or $\mathrm{T}_{\mathrm{b}}$ with a version to predict the transient temperature profiles was elaborated, presented, and validated. The model is based on a quadratic $\mathrm{v}_{\mathrm{w}}$ function multiplied with a correction function accounting for the change in $\eta_{\mathrm{pv}}$ due to the deviation of the environmental conditions from their average values taken as reference. An excellent agreement under any environmental conditions was confirmed between predicted and recorded PV module $\mathrm{T}_{\mathrm{b}}$ values, deviation $<3 \%$, in comparison with other 6 known models. The model performed better than any other one. Accurate PV temperature prediction is especially important considering its significant effect on $\mathrm{PV}$ power output, with a typical value for the temperature coefficient of $\mathrm{P}_{\mathrm{m}}$ of $-0.5 \% /{ }^{\circ} \mathrm{C}$. Considering that a range of $5-25 \%$ reduction in power output is normally expected from the nominal value for $1000 \mathrm{~W} / \mathrm{m}^{2}$ incident irradiance due to PV temperature alone, accurate prediction of $\mathrm{PV}$ temperature can assist in adequate control measures, monitoring and diagnostic procedures to be taken in practical situations of PV installations.

Finally, a mathematical algorithmic expression was developed to predict the transient $T_{b}(t)$, $T_{g}(t), T_{c}(t)$. The time constant of the $T_{b}(t)$ profiles for the PV modules theoretically derived and experimentally determined deviated by less than $5 \%$. The accuracy can be further increased with a more analytical determination of $U_{f}$ and $U_{b}$ as in [23]. The transient model provided also a simple expression for the steady state $\mathrm{T}_{\mathrm{b}}$ whose deviation from the theoretical and experimental values was less than $5.8 \%$. The transient $\mathrm{T}_{b}(\mathrm{t})$ profile produced by the model followed closely the measured $\mathrm{T}_{\mathrm{b}}$ data, as was shown in many cases examined in a bare c-Si cell and also in $3 \mathrm{c}-\mathrm{Si}$ and pc-Si PV modules. The compact model developed is applicable to any geographical site and environmental conditions.

Author Contributions: Data curation, S.K.; Formal analysis, E.K.; Investigation, S.K.; Methodology, S.K. and E.K.; Resources, S.K.; Software, E.K.; Validation, E.K.; Writing一original draft, S.K.; Writing-review and editing, S.K. and E.K.

Funding: This research received no external funding.

Acknowledgments: The authors acknowledge the technical support of I. Kalidiris in data collection, logging and analysis of measured PV module temperatures.

Conflicts of Interest: The authors declare no conflict of interest.

Nomenclature

\begin{tabular}{llll}
\hline ANN & Artificial Neural Networks & $\mathrm{U}_{\mathrm{f}}=\mathrm{U}_{\mathrm{g}-\mathrm{a}}$ & $\begin{array}{l}\text { Heat losses coefficients due to convection } \\
\text { and IR radiation at the front side of the } \\
\mathrm{PV} \text { module }\left(\mathrm{W} / \mathrm{m}^{2} \mathrm{~K}\right), \text { equal to } \mathrm{h}_{\mathrm{c}, \mathrm{f}}+\mathrm{h}_{\mathrm{r}, \mathrm{f}}\end{array}$ \\
\hline BAPV & Building Adapted Photovoltaics & $\mathrm{V}_{\mathrm{oc}}$ & $\begin{array}{l}\text { Open circuit voltage in a PV cell or } \\
\text { module }(\mathrm{V})\end{array}$ \\
\hline BIPV & Building Integrated Photovoltaics & $\mathrm{h}_{\mathrm{c}, \mathrm{f}}$ & $\begin{array}{l}\text { Heat convection coefficient from PV glass } \\
\text { to air }\end{array}$ \\
\hline EBE & Energy Balance Equation & $\mathrm{h}_{\mathrm{r}, \mathrm{f}}$ & $\begin{array}{l}\text { Radiative heat coefficient from the front } \\
\text { PV side }\left(\mathrm{W} / \mathrm{m}^{2} \mathrm{~K}\right)\end{array}$ \\
\hline FIX & Fixed inclination PV installation & $\mathrm{h}_{\mathrm{c}, \mathrm{b}}$ & $\begin{array}{l}\text { Heat convection coefficient from PV back } \\
\text { surface to air }\left(\mathrm{W} / \mathrm{m}^{2} \mathrm{~K}\right)\end{array}$ \\
\hline
\end{tabular}




\begin{tabular}{|c|c|c|c|}
\hline $\mathrm{I}_{\mathrm{T}}$ & $\begin{array}{l}\text { Global solar radiation intensity on the } \\
\text { tilted PV plane }\left(\mathrm{W} / \mathrm{m}^{2}\right)\end{array}$ & $\mathrm{h}_{\mathrm{r}, \mathrm{b}}$ & $\begin{array}{l}\text { Radiative heat coefficient from the PV } \\
\text { back side to environment }\left(\mathrm{W} / \mathrm{m}^{2} \mathrm{~K}\right)\end{array}$ \\
\hline $\mathrm{I}_{\mathrm{T}, \mathrm{ref}}$ & It is the $\mathrm{I}_{\mathrm{T}}$ equal to $10^{3} \mathrm{~W} / \mathrm{m}^{2}$ & $\mathrm{k}_{\mathrm{i}}$ & $\begin{array}{l}\text { Thermal conductivity of cell layer i } \\
(\mathrm{W} / \mathrm{mK})\end{array}$ \\
\hline $\mathrm{I}_{\mathrm{ph}}$ & The photo-current of the PV cell (A) & $(\mathrm{mc})$ & Mass heat capacity $(\mathrm{J} / \mathrm{K})$ \\
\hline $\mathrm{I}_{\mathrm{sc}}$ & $\begin{array}{l}\text { Short circuit current from a PV cell or } \\
\text { module (A) }\end{array}$ & $\mathrm{n}$ & The ideality factor of the PV cell diode \\
\hline $\mathrm{P}_{\mathrm{m}}(\mathrm{t})$ & PV power output at MPP at time $t(W)$ & $\mathrm{v}_{\mathrm{w}}$ & Wind velocity (m/s) \\
\hline ST & Sun-tracking system & $\delta x$ & Cell layer thickness (m) \\
\hline $\begin{array}{l}\mathrm{T}_{\mathrm{pv}}, \mathrm{T}_{\mathrm{c}} \\
\mathrm{T}_{\mathrm{f}}, \mathrm{T}_{\mathrm{b}}\end{array}$ & $\begin{array}{l}\text { PV module temperature, PV } \\
\text { semiconductor temperature, PV front } \\
\text { side and PV back side temperatures, } \\
\text { respectively }\end{array}$ & $\varepsilon_{\mathrm{pv}}, \varepsilon_{\mathrm{b}}$ & $\begin{array}{l}\text { Emissivity coefficients of the PV glass and } \\
\text { back surface, respectively }\end{array}$ \\
\hline $\mathrm{T}_{\mathrm{g}}$ & PV glass cover temperature $=\mathrm{T}_{\mathrm{f}}\left({ }^{\circ} \mathrm{C}\right)$ & $\begin{array}{l}\eta_{\mathrm{c}}, \eta_{\mathrm{pv}} \\
\eta_{\mathrm{pv}, \mathrm{m}}\end{array}$ & $\begin{array}{l}\text { PV cell and module efficiency, } \\
\text { PV module efficiency at average } \\
\text { environmental conditions }\end{array}$ \\
\hline $\mathrm{T}_{\mathrm{a}}$ & Ambient temperature $(\mathrm{K})$ & $\rho$ & Density $\left(\mathrm{kg} / \mathrm{m}^{3}\right)$ \\
\hline $\mathrm{U}_{\mathrm{b}}=\mathrm{U}_{\mathrm{b}-\mathrm{a}}$ & $\begin{array}{l}\text { Heat losses coefficients due to } \\
\text { convection and IR radiation at the back } \\
\text { side of the PV module }\left(\mathrm{W} / \mathrm{m}^{2} \mathrm{~K}\right) \text {, equal } \\
\text { to } \mathrm{h}_{\mathrm{c}, \mathrm{b}}+\mathrm{h}_{\mathrm{r}, \mathrm{b}}\end{array}$ & $\tau$ & $\begin{array}{l}\text { Time constant of the PV module or cell } \\
\text { temperature profile }\end{array}$ \\
\hline $\mathrm{U}_{\mathrm{pv}}$ & $\begin{array}{l}\text { The overall heat losses coefficient from } \\
\text { a PV }\left(\mathrm{W} / \mathrm{m}^{2} \mathrm{~K}\right) \text {, equal to } \mathrm{U}_{\mathrm{f}}+\mathrm{U}_{\mathrm{b}}\end{array}$ & $(\tau \alpha)$ & Transmittance-absorptance product \\
\hline
\end{tabular}

\section{References}

1. King, D.L.; Boyson, W.E.; Kratochvill, J.A. Photovoltaic Array Performance Model; SAND2004-3535; Sandia National Laboratories: Albuquerque, NM, USA; Livermore, CA, USA, 2004.

2. Faiman, D. Assessing the outdoor operating temperature of photovoltaic modules. Prog. Photovolt. Res. Appl. 2008, 16, 307-315. [CrossRef]

3. Skoplaki, E.; Palyvos, J.A. On the temperature dependence of photovoltaic module electrical performance: A review of efficiency/power correlations. Sol. Energy 2009, 83, 614-624. [CrossRef]

4. Mattei, M.; Notton, G.; Cristofari, C.; Muselli, M.; Poggi, P. Calculation of the polycrystalline PV module temperature using a simple method of energy balance. Renew. Energy 2006, 31, 553-567. [CrossRef]

5. Mani, T.G.; Ji, L.; Tang, Y.; Petacci, L.; Osterwald, C. Photovoltaic Module Thermal/Wind Performance: Long Term Monitoring and Model Development for Energy Rating. In Proceedings of the NCPV and Solar Program Review Meeting, Denver, CO, USA, 24-26 March 2003.

6. Fuentes, M.K. A Simplified Thermal Model for Flat-Plate Photovoltaic Modules; SAND85-0330 UC-63; Sandia National Laboratories: Albuquerque, NM, USA; Livermore, CA, USA, 1987.

7. King, D.L. Photovoltaic module and array performance characterization methods for all system operating conditions. In Proceedings of the NREL/SNL Photovoltaics Program Review Meeting, Lakewood, CO, USA, 18-22 November 1996; AIP Press: New York, NY, USA, 1997.

8. Mora Segado, M.; Carretero, J.; Sidrach-de-Cardona, M. Models to predict the operating temperature of different photovoltaic modules in outdoor conditions. Prog. Photovolt. Res. Appl. 2015, 23, 1267-1282. [CrossRef]

9. Hammami, M.; Torretti, S.; Grimaccia, F.; Grandi, G. Thermal and Performance analysis of a Photovolatic Module with an Integrated Energy Storage System. Appl. Sci. 2017, 7, 1107. [CrossRef]

10. Ciulla, G.; Lo Brano, V.; Moreci, E. Forecasting the cell temperature of PV modules with an adaptive system. Int. J. Photoenergy 2013, 2013, 192854. [CrossRef] 
11. Kaplanis, S. Determination of the electrical characteristics and thermal behaviour of a c-Si cell under transient conditions for various concentration ratios. Int. J. Sustain. Energy 2016, 35, 887-992. [CrossRef]

12. Tina, G.M.; Marletta, G.; Sardella, S. Multy-layer thermal models of PV modules for monitoring applications. In Proceedings of the 38th IEEE Photovoltaic Specialists Conference, Austin, TX, USA, 3-8 June 2012. [CrossRef]

13. Jones, A.D.; Underwood, C.P. A Thermal Model for Photovoltaic Systems. Sol. Energy 2001, 70, 349-359. [CrossRef]

14. Shahzada, P.A.; Ahzi, S.; Barth, N.; Abdallah, A. Using energy balance method to study the thermal behavior of PV panels under time varying field conditions. Energy Convers. Manag. 2018, 175, 246-262.

15. Kayhan, O. A thermal model to investigate the power of solar array for stratospheric balloons in real conditions. Appl. Therm. Eng. 2018, 139, 13-120. [CrossRef]

16. Brinkworth, B.J.; Marshall, R.H.; Ibarahim, Z. A validated model of naturally ventilated PV cladding. Sol. Energy 2000, 69, 67-81. [CrossRef]

17. Armstrong, S.; Hurley, W.G. A thermal model for photovoltaic panels under varying atmospheric conditions. Appl. Therm. Eng. 2010, 30, 1488-1495. [CrossRef]

18. Trinuruk, P.; Sorapipatana, C.; Chenvidhya, D. Estimating operating cell temperature in BIPV modules in Thailand. Renew. Energy 2009, 34, 2515-2523. [CrossRef]

19. AssoaYa, B.; Zamini, S.; Sprenger, W.; Misara, S.; Pellegrino, M.; Erleaga, A.A. Numerical Analysis of the Impact of Environmental Conditions on BIPV: An Overview of the BIPV Modelling in SOPHIA Project. In Proceedings of the 27th European Photovoltaic Solar Energy Conference and Exhibition, Frankfurt, Germany, 24-28 September 2012; pp. 4143-4149.

20. Jakhrany, A.Q.; Othman, A.K.; Rigit, A.R.H.; Samo, S.R. Comparison of Solar Photovoltaic Temperature Models. World Appl. Sci. J. 2011, 14, 1-8.

21. Kaplanis, S.; Kaplani, E. A PV temperature prediction model for BIPV configurations, comparison with other models and experimental results. In Proceedings of the 9th International Workshop on Teaching in Photovoltaics (IWTPV 2018), Prague, Czech Republic, 15-16 March 2018; Ceske Centrum IET. pp. 20-26.

22. Kamuyu, W.C.L.; Lim, J.R.; Won, C.S.; Ahn, H.K. Prediction model of Photovoltaic Module Temperature for Power Performance of Floating PVs. Energies 2018, 11, 447. [CrossRef]

23. Kaplani, E.; Kaplanis, S. Thermal modelling and experimental assessment of the dependence of PV module temperature on wind velocity and direction, module orientation and inclination. Sol. Energy 2014, 107, 443-460. [CrossRef]

24. Kaplani, E.; Kaplanis, S. PV module temperature prediction at any environmental conditions and mounting configurations. In Proceedings of the World Renewable Energy Congress (WREC'18), London, UK, 30 July-3 August 2018.

25. Akhasassi, M.; El Fathi, A.; Erraissi, N.; Aarich, N.; Bennouna, A.; Raoufi, M.; Outzourhit, A. Experimental investigation and modeling of the thermal behaviour of a solar PV module. Sol. Energy Mater. Sol. Cells 2018, 180, 271-279. [CrossRef]

26. KouadriBoudjelthia, E.A.; Abbas, M.L.; Semaoui, S.; Kerkouche, K.; Zeraïa, H.; Yaïche, R. Role of the wind speed in the evolution of the temperature of the PV module: Comparison of prediction models. Rev. Energies Renouvelables 2016, 19, 119-126.

27. Schwingshackl, C.; Petitta, M.; Wagner, J.E.; Belluardo, G.; Moser, D.; Castelli, M.; Zebisch, M.; Tetzlaff, A. Wind effect on PV module temperature: Analysis of different techniques for an accurate estimation. Energy Procedia 2013, 40, 77-86. [CrossRef]

28. Mittelman, G.; Alshare, A.; Davidson, J.H. A model and heat transfer correlation for rooftop integrated photovoltaics with a passive air cooling channel. Sol. Energy 2009, 83, 1150-1160. [CrossRef]

29. Saadon, S.; Gaillard, L.; Giroux-Julien, S.; Menezo, C. Simulation study of a naturally-ventilated building integrated photovoltaic/thermal, BIPV/T, envelope. Renew. Energy 2016, 87, 517-531. [CrossRef]

30. Ciulla, G.; Lo Brano, V.; Franzitta, V.; Trapanese, M. Assessment of the operating temperature of crystalline PV modules based on real use conditions. Int. J. Photoenergy 2014, 2014, 718315. [CrossRef]

31. Rubin, L.; Nebusov, V.; Leutz, R.; Schneider, A.; Osipov, A.; Tarasenko, V. DAY4TM PV Receivers and Heat Sinks for Sun Concentration Applications. In Proceedings of the 4th International Conference on Solar Concentrators for the Generation of Electricity or Hydrogen, El Escorial, Spain, 12-16 March 2007. 
32. Peng, C.; Yang, J. The effect of Photovoltaic Panels on the Rooftop Temperature in the EnergyPlus Simulation Environment. Int. J. Photoenergy 2016, 2016, 9020567. [CrossRef]

33. Misara, S. Thermal Impacts on Building Integrated Photovoltaics (BIPV). Ph.D. Thesis, Universitat Kassel, Kassel, Germany, 2014.

34. Lienhard, J.H., IV; Lienhard, J.H., V. A Heat Transfer Textbook, 3rd ed.; Phlogiston Press: Cambridge, MA, USA, 2000.

35. Dupont, Tedlar PVF Films for Industrial Applications. Available online: www.tedlar.com (accessed on 20 October 2018).

36. Webb, J.E.; Wilcox, D.I.; Wasson, K.L.; Gulati, S.T. Specialty thin glass for PV modules: Mechanical Reliability Considerations. In Proceedings of the 24th European Photovoltaic Solar Energy Conference and Exhibition, Hamburg, Germany, 21-25 September 2009.

37. Ross, R.G. Interface design considerations for terrestrial solar cell modules. In Proceedings of the 12th IEEE Photovoltaic Specialist's Conference, Baton Rouge, LA, USA, 15-18 November 1976; pp. 801-806.

38. D’Orazio, M.; Di Perna, C.; Di Giuseppe, E. Experimental operating cell temperature assessment of BIPV with different installation configurations on roofs under the Mediterranean climate. Renew. Energy 2014, 68, 378-386. [CrossRef]

39. Muller, M.T.; Rodriguez, J.; Marion, B. Performance comparison of a BIPV roofing tile system in two mounting configurations. In Proceedings of the 2009 34th IEEE Photovoltaic Specialists Conference, Philadelphia, PA, USA, 7-12 June 2009.

40. Pantic, S.; Candanedo, L.; Athienitis, A.K. Modeling of energy performance of a house with three configurations of building-integrated photovoltaic/thermal systems. Energy Build. 2010, 42, 1779-1789. [CrossRef]

41. Kaplanis, S.; Kaplani, E. On the relationship factor between the PV module temperature and the solar radiation on it for various BIPV configurations. AIP Conf. Proc. 2014, 1618, 341-347. [CrossRef]

(c) 2018 by the authors. Licensee MDPI, Basel, Switzerland. This article is an open access article distributed under the terms and conditions of the Creative Commons Attribution (CC BY) license (http:/ / creativecommons.org/licenses/by/4.0/). 